\title{
Rant Etkisinde Zekeriyaköy: Çepere Yönelen Plan, Yatırım ve Kullanıc Tercihlerine Dair Bir Araştırma
}

\author{
Zekeriyaköy Under Rental Impact: A Research on Plan, \\ Investment and User Preferences at the Periphery
}

\author{
Elif Menteş, ${ }^{1}$ (iD Evrim Töre ${ }^{2}$
}

${ }^{1}$ İstanbul Kültür Üniversitesi, Fen Bilimleri Enstitüsü, Mimarlık Yüksek Lisans, İstanbul

${ }^{2}$ İstanbul Kültür Üniversitesi, Mimarlık Fakültesi, Mimarlık Bölümü, İstanbul

\section{ÖZ}

Dönemin temel sektörü olması dolayısıyla tarım sektörüne bağlı olarak iktisat alanında ortaya çıkmış ve gelişmiş olan rant teorileri ve araştırmaları bugün kentsel planlama alanında önemli bir yere sahiptir. Bununla birlikte mevcut çalışmaların ağırlıkla kuramsal tartışmalardan ibaret olduğu ve konuyla ilgili durum çalışmalarının yeterli düzeyde olmadığı gözlenmiştir. Bu makalede rant olgusu, rantı yaratan faktörler ve aktörler kentleşme baskısının çok yüksek olduğu İstanbul'da, üst gelir grubunun yerleşme için tercih ettiği çeper alanlardan biri olan Zekeriyaköy örneği üzerinden ele alınmıştır. Teorik çalışmaların altını çizdiği rant unsurlarından hareketle çalışmada kullanılmak üzere Alan için tanımlanan rant göstergeleri arasında; nüfus artışı, yerleşim alanının büyümesi, altyapının gelişimi, sokak sayısındaki artış, konut tipolojisi ve niteliklerinde değişiklik, arsa ve konut metrekare değerlerinde artış, ulaştırma altyapısının gelişimi yer almaktadır. Alan sakinleriyle yapılan anketler, kurum ve kuruluşların temsilcileriyle yapılan derinlemesine mülakatlar ve alanda yapılan analiz ve gözlemler çalışmanın başlıca kaynaklarını oluşturmuştur. Çalışma bulguları, 1980'lerin ortalarında yetmiş hanelik bir köy yerleşimi olan Zekeriyaköy'ün birkaç on yıl içinde yatayda ve kısmen düşeyde gelişerek büyüdüğüne ve bu büyümede rant olgusunun varlığına dikkat çekmekte, merkezi ve yerel kamu aktörlerinin özellikle ulaşım ve konut alanlarındaki plan, proje ve yatırımları ile, planlarla önü açılan özel sektör yatırımlarına, özellikle de üst gelir grubunu hedefleyen lüks konut projelerine işaret etmektedir. Zekeriyaköy'de rant unsurunu ortaya çıaran bir diğer olgu 1999 Marmara depreminin ardından İstanbul'un deprem riskli güney bölgelerinde yaşamakta olan bir kesimin kuzeye, deprem güvenlikli alanlara doğru yer değiştirme eğilimleri olmuştur. Bu eğilim; alanda zaten 1990'lardan beri var olan konut geliştirme projeleri, alanın doğa ile iç içe yapısı,

\section{ABSTRACT}

As the basic sector of the period, rent theories and research findings that have emerged in the field of economics have an important place in urban planning today. However, it has been observed that current studies consist mainly of theoretical debates and that there are insufficient case studies available. In this article, the phenomenon of rent, factors that create rent and the actors involved are discussed in the context of Zekeriyaköy, a peripheric area preferred by Istanbul's upper income group where urbanization pressure is high. The indicators of rent used in this study are based on the rent elements emphasized by theoretical studies, including population growth, settlement area growth, infrastructure development, increase in the number of streets, changing housing typology and qualities, increase in land and residential square meter values and development of transportation infrastructure. Resident surveys, interviews with representatives of institutions and organizations, and analysis of observations in the field were the main sources. The findings indicate that Zekeriyaköy, originally a settlement of seventy households in the mid-1980s, has grown largely horizontally over a few decades, and the presence of a rent effect in this growth. The findings stress private sector investments, particularly luxury housing projects. Another phenomenon revealing the rent element in Zekeriyaköy is the tendency to move to earthquake-safe areas in the north, following the 1999 Marmara earthquake. This trend has become an attractive element, especially for the upper income group, regarding the housing development projects, the nature of the area, its proximity to

Geliş tarihi: 25.09.2019 Kabul tarihi: 22.05.2020

Online yayımlanma tarihi: I4.10.2020

İletişim: Elif Menteş

e-posta: evrim.ozkan@yahoo.com 
kent merkezine yakınlı̆̆ ve ulaşım proje ve yatırımları gibi etkenlerle birleştiğinde, özellikle üst gelir grubu için çekici bir unsur haline gelmiştir. Dolayısıyla, hedef kitleye bağlı olarak konut tiplerinde ve özelliklerinde ortaya çıkan değişiklik de sözü edilen rantın sebepleri arasındadır. Zekeriyaköy'deki değer artışları, alanın kent merkezine göre konumu bağlamında değerlendirildiğinde "farklılık rantı"na örnek gösterilebilirken, parsellerin yatırımcılarına toprakların bugünkü piyasa değerleri bağlamında artı-değer yaratması açısından "tekel rantı"nın niteliklerini sergilemektedir. Bununla birlikte söz konusu değer artışları, alan sakinlerinde, mülklerini satma ya da kiralama eğilimi yaratmamaktadır.

Anahtar sözcükler: Büyük projeler; merkezi ve yerel kamu aktörleri; planlama; rant; Zekeriyaköy. the city center and transportation projects and investments. Therefore, the change in housing types and properties relative to the target audience is among the reasons for the rent. When value increases in Zekeriyaköy are evaluated in the context of location, relative to the city center, an example of "difference rent" can be shown. The area demonstrates the characteristics of the "monopoly rent", in creating surplus value for the investors of the parcels in the context of current market values. Those value increases have not appeared to create an intention to sell or rent property amongst the existing inhabitants of the neighborhood.

Keywords: Big projects; central and public actors; planning; rent; Zekeriyaköy.

\section{Giriş}

Hakim sektörün tarım olduğu dönemde ilk kez I700'lü yılların başında William Petty tarafından ortaya atılmış olan rant teorisi, sermayenin kâr yaratması bağlamında tartışılmıştır. Ürünün Pazar fiyatının belirlenmesinde maliyet unsurunu ve bu unsurun tarlanın yeri ile ilişkisini dayanak alarak gelişen, Ricardo, Marx gibi teorisyenleri de içine alan tartışmalar, kentlerdeki sanayileşme dönemi etkilerinin belirginleşmesiyle birlikte; değişim değeri, kâr, rant, ücret, aktör ilişkileri çerçevesinde ele alınmaya başlamıştır. Bugün gelinen noktada ise rantın yaygın olarak; toprak üzerinden, emek harcamadan kazanç elde etme eğilimi bağlamında yorumlandığı görülmektedir. Nitekim söz konusu eğilim yapılaşma baskısı ile buluştuğunda, kimi zaman değerli tarım alanlarının, kimi zamansa doğal alanların kent toprağına dönüşmesine, zaman içinde ise kentleşmesine neden olmaktadır. Kent toprağı, kapitalist üretim ve tüketim biçimleri için bir meta haline gelmiştir. "Rant”, bu metalaşma sürecinde, kimi zaman bir girdi, kimi zamansa sürecin çıtısı olarak var olmaktadır.

Yukarıda kısaca yer verilen süreçlere paralel olarak, İstanbul'da da imarlı alanlar yerel yönetimlerin kararları ve artan nüfus nedeniyle genişlemiştir. Bu genişleme, kent çeperindeki tarım topraklarının ve doğal alanların önce kent toprağına, imar uygulaması sonrasında ise arsaya dönüşmesine neden olmuştur. Çalışma alanı olarak seçilen Zekeriyaköy, bir yandan bu genişleme baskısıyla kent merkezinin dışında oluşması, bir yandan ise kent merkezine erişilebilirliği karayolu çalışmalarıyla her geçen gün daha da arttığı gözlenen bir örnek olması açısından önemlidir. Bu sebeple; çalışma içerisinde rant olgusu, İstanbul'un Sarıyer İlçesi mahallelerinden biri olan Zekeriyaköy örneği üzerinden okumaktadır.

19. yy. sonlarında Kafkas ve Kırım'dan savaş nedeniyle göç eden birkaç ailenin yerleştiği Zekeriyaköy, zaman içerisinde Karadeniz Bölgesi'nden göç alarak büyümüş, 1980’lerde 2-3 katlı ve bahçeli 70 kadar evden oluşan bir köy yerleşimi haline gelmiştir (İstanbul Büyükşehir Belediyesi Şehir Planlama Mü- dürlüğü, 2003). Alanın, köy yerleşimcileri dışında, bir mesken alanı olarak kullanılmaya başlaması, 1987 yılında yerel yönetim tarafından bazı parsellerin imara açılmasıyla tetiklenmiştir. Zaman içerisinde ulaşım altyapısı, büyük projeler ve yatırımlar açısından ortaya çıkan gelişmeler, doğaya ve doğal yaşama olan ilginin artması Zekeriyaköy'ü daha çekici hale getirmiştir. Bu eğilimlerin yerel yönetimin mahalleye dair plan ve projelerinde de görünür olduğu bilinmektedir. Çekici faktörlerin yanı sıra, deprem, kent merkezindeki yoğunluğun artması gibi itici öğeler de kentin merkezi alanlarında birikmiş olan nüfusun çepere kayma eğilimini artırmış, Zekeriyaköy söz konusu nüfus hareketini karşılayan lokasyanlardan biri olmuştur. Erişilebilirliği, kentin gürültü ve kirliliğinden uzak doğası (Sarıyer Belediyesi, 2003), müstakil yaşama olanağı tanıması gibi nedenler alana cazibe kazandırmıştır. Son yıllarda ise, alanın erişilebilirliği artarken, alanı çekici kılan diğer faktörlerin giderek zayıfladığı, bununla birlikte alanın bir yatırım aracı olarak hızla bir çekim noktası haline gelmekte olduğu gözlenmektedir. Bu cazibenin temel göstergeleri arasında emlak fiyatlarındaki kayda değer artış ve çok sayıda projenin inşa edilmekte oluşu sayılabilir. Sözü edilen yönelim, Zekeriyaköy'ün tercih edilme nedenleri ile çelişmekte, giderek artan yapılaşma, alanın söz konusu doğal yapısına zarar vermektedir.

Bu ön bilgilerden hareketle oluşan hipotez; Zekeriyaköy'ün son dönem gelişimini çeşitli merkezi ve yerel plan ve projelerin etkisiyle ortaya çıkmış olan "rant" olgusunun yönlendirmekte olduğudur. Bu bağlamda planlama, imar hakları aracılığıyla rant yaratan ve/veya rantı tetikleyen bir mekanizma olarak öne çıkmaktadır. Çalışma kapsamında açılacak olan araştırma sorularından ilki; alanın gelişme sürecinde hangi parametrelerin etken olduğudur. Söz konusu parametreler; bir sonraki bölümde rantı ortaya çıkaran faktörler ve rantın sonuçları, rant türleri, rantın hangi göstergelerle ölçülebileceği gibi temel konulara dair kavramsal çerçeve yardımıyla ortaya konmuştur. İkinci araştırma sorusu ise, rantın gayrimenkul fiyatlarında yarattığı artış, alan sakinlerinde mülklerini satma/kiralama eğilimi yaratıp yaratmadığıdır. Bir başka değişken gayrimenkulün kullanım değerinin mi yoksa değişim değerinin mi baskın oldu- 
ğu incelenmiştir. Ardından, bu çerçevenin yön verdiği yöntem ve materyaller sunulmuştur. Alan çalışmasından elde edilen ve tartışılan bulgular Sonuç bölümünde değerlendirilmiştir.

\section{Rant Kavramının Gelişimi, Rant Türleri ve Kavrama İlişkin Güncel Tartışmalar}

Klasik rant teorileri, dönemin temel sektörü olması dolayısıyla tarım sektörüne bağlı olarak ortaya çıkmış ve gelişmiştir. Ürünün Pazar fiyatının belirlenmesinde maliyet unsurunun önemi büyüktür ki, bu unsur tarlanın yeri ile doğrudan ilişkilidir. Uzak lokasyonlarda gerçekleşen üretimin maliyeti, Pazar fiyatının belirlenmesinde belirleyici olmadığında çiftçiler için karlı olmaktan çıkacağı ve tarım sektöründe kayıp yaşanacağından, Pazar fiyatı en kötü durumda olan üretim fiyatlarının seviyesine göre belirlenmektedir (Park, 20II). Bu bağlamda, pazara/tüketim lokasyonlarına en yakın olan arazi (tarla), daha düşük maliyetle üretim yapacak ve piyasa fiyatı ile üretim maliyeti arasındaki farkı içeren bir kar elde edecektir. Bu artı değeri elde etmek isteyen çiftçiler daha yakın lokasyonlarda arazi arayışına girecek, benzer şekilde arazi sahipleri de bu değer fazlasından pay alabilmek için topraklarını kiralama eğiliminde olacaktır. Burada bir değer bölüşümü söz konusudur. Aşağıda kısaca, rant kavramının odağında olan bu değere ilişkin teorik tartışmaların gelişimine ve rant türlerine yer verilmektedir.

17. yüzyılın ilk çeyreğinde doğan William Petty rant kavramını ilk kullanan teorisyen olarak bilinmektedir. IIlk kez Petty, üretim alanının, sermayenin yarattığı kârın çıkış noktası olduğunu öne sürmüştür. Emeğin harcandığı süreyi değerin parametrelerinden biri olarak kullanan ve fazlasının artı-değer olduğu görüşünü benimseyen Petty'nin teorisi içerisinde artı-değerin tamamı rantı oluşturmaktadır (Turan, 2009). David Ricardo (1772-1823) ise toprakların birbirinden farklı özelliklere sahip olduğunu, bazılarının üretime diğerlerinden daha çok katkı sağladıklarını, bu sebeple de bu toprakların diğerlerinden daha değerli olabileceği düşüncesiyle, rantın ortaya çıkışını toprakların farklılığıyla bağdaştırmıştır. Ricardo'ya göre rant aslında, kaliteli toprağın az bulunması sebebiyle doğmuştur (Üstünel, 200I). 19. yüzyılının önemli teorisyenlerinden biri olan Karl Marx'ın rant teorilerine katkısına bakıldığında, değişim değeri ile, kâr, rant ve ücretlerin, hangi aktörlerle nasıl ilişkiler kurduğunu aydınlattı̆̆ı görülmektedir. Rantı, kâr ve faizle birlikte ödenmemiş emek olarak nitelendiren Marx'a göre emekçinin harcadığı emeğin değeri, ailesini geçindirebileceği miktarla paraleldir ve fazlası artı-değer yaratır (Turan, 2009). Rant ve kâr, değerden alınan paydır. Rantın, sermayeye duyulan ilgiye benzer bir durumu vardır. Toprak rantı, değer yaratan toprağın mülkiyeti, emekçi grup ve sermaye sahibi olan endüstriyel kapitalist tarafından oluşan bir olgudur. Marx, konum faktörünü, konunun dışında tutar. Konum ile ilgili konular üreticinin iradesi ile ayrıca değiştirilmeye yatkındır (Harvey, 2006).
Kentsel rant incelenirken, birçok rant tipi ortaya çıkmıştır ancak en yaygın görülen üç rant türü; farklılık rantı, tekel rantı ve mutlak ranttır. Sırasıyla bakmak gerekirse, klasik iktisatçılara göre, toprakların farklı üretim koşulları, Farklılık Rantının ana kaynağıdır. Ricardo ve Marx'ın da tartıştı̆̆ı üzere bu rant türü, üzerinde üretim yapılması amaçlanan toprak parçasına yapılan yatırım ile ilişkilidir. Yani aynı durumda olan iki toprak parçasından birine daha fazla yatırım yapıldığında elde edilen ürün daha fazla olacağından, yatırım yapılan topraktaki üreticinin kârı da daha fazla olacaktır. Farklılık rantı, iki üreticinin kazancı arasında doğan fark olarak ifade edilmektedir (Harvey, 2006). Güncel tartışmalarda ise bu rant tipi, bir toprak parçasının kente göre olan konumu ile alakalıdır. Kent büyüdükçe, çeperin dışında kalan tarım topraklarının kentsel arsaya dönüşme ihtimali farklılık rantını oluşturur. Rant teorilerinden ikincisi Tekel Rantıdır. Bir arsanın kent içerisindeki konumuna bağı olarak, mülkiyetinde bulunduğu kişi ve kurumlara yarattığı kârdır. Örneğin miras kalan bir arsanın lokasyonel olarak Boğaz'da yer alması, bu arsa üzerinde herhangi bir emek harcamaya gerek duymadan miras kalan kişiye artı-değer yaratmaya başlayacaktır. Sonuncu rant tipi ise Mutlak Ranttır. Marx’a göre mutlak rant, herhangi bir arsada, değerlendirilen mutlak verimlilik üzerinden elde edilen birikimdir. Toprak sahibi daha sonra bu topraktan, ödenen mutlak rant ile ortalama ve azami fayda sağlamaktadır. Bu gelir ödenen toplam kiranın bir parçasıdır. Mutlak rant, topraktaki özel sahiplik durumu ile bağlantılıdır (Turan, 2009). Günümüzde bu rant tipi, yerel yönetimlerce belirlenen kanunlar neticesinde ortaya çıkan kıtlığa bağı olarak değerlendirilmektedir. Bir toprak parçasının bulunduğu bölgedeki imar durumu değiştiği zaman söz konusu toprağın etrafı yapılaşmaya başlamaktadır. Etrafında yaşanmaya başlayan bu değişim, üzerine herhangi bir yatırım yapmaya gerek duymadan, zamanla toprağın fiyatını arttıracaktır. Bu anlamda diğer rant türlerinden farklıdır. Diğer rant türlerinde toprak sahibinin beklemesi yeterliyken, mutlak rantta toprak sahibi, yerel yönetimler ve benzeri aktörler yardımıyla bir strateji izleyip mülkiyetinde bulunan toprağın değerini arttırabilir. Kamu kuruluşlarının bölgedeki plan, proje ve yatırımları toprak sahibine artı-değer olarak dönmektedir (Aydemir vd., 2004).

Yukarıda yer verilen bu tasniflemeye ilişkin kavramsal bir mutabakat olmadığı hatırlanmalıdır. Örneğin Harvey (1974), mutlak rant yerine "sınif-tekel rantı (class-monopoly rent)" tanımını kullanmış, Scott (1976) ve Lipietz (1985) gibi teorisyenler, mutlak rant ve tekel rantının farklı olmadığını ileri sürmüştür. Jaèger (2003) mutlak rant kavramını reddetmektedir. Yazara göre bu bir rant türü değildir. Evans ise (1999) mutlak rantın bir maliyetler ve riskler toplamı olduğunu savunmaktadır.

Jaèger (2003), evrensel bir rant teorisinin reddine dair tartı̧̧malara dikkat çekmektedir. Arazi rantı kuramı, tutarlı ve geniş çapta kabul görmüş bir kuramsal yapıya sahip değildir ve merkezi kategorilerinde bile çeşitli farklı kavramsallaştırmadan 
oluşur. Dahası, teori genellikle, ampirik veya daha somut uygulamaları daha zor hale getiren nispeten yüksek bir soyutlama seviyesinde geliştirilir. Harvey dahi (1985) siyasi-ekonomik kalkınma, kentsel arazi rantı ve yerleşim farklılaşması arasında ikna edici bir bağlantı sağlamamaktadır (Jaèger, 2003). Klasik, ancak Marksist bir bakış açısından üretilen bir meta için fiyatlar, üretim maliyetlerine bağlıdır. Kentsel arazinin tek bir firma tarafından kapitalist üretim süreci olmadığı için, arazinin fiyatını belirleyen faktörler, ortak bir kapitalist metadan farklıdır. Böylece, arazinin kendine özgü bir muamelesi ve ona bağlı sosyal ilişkiler gereklidir. Bu nedenle, özel bir teori - arazi rant teorisi - geliştirilmiştir (Jaèger, 2003).

Harvey (1982), arazinin giderek bir finansal varlık/değer haline geldiğinden söz etmektedir. Bugün, kârlı yatırım fırsatlarını umutsuzca artan artı-sermaye miktarı, spekülatif finansal yatırımların ikincil sermaye çevriminde dolaşmakta ve özellikle de türev finansal ürünlere ve finansal varlıklarla uğraşmakta olan işlere uzanmaktadır. Ampirik tahminlere göre, bugün dünya sermayesinin ikincil çevrimlerinin dünya hacminin, dünya GSYIH'sı tarafından ölçülen sermayenin birincil çevriminin hacminden 65 kat daha büyük olduğunu söyleyebiliriz (Kratke, 20I4).

Tüm bu tartışmaların ışığında "rant”, herhangi bir emeğe veya sermayeye ihtiyaç duyulmadan, taşınmazın sahip olduğu değerin artması olarak tarif edilebilir. Doğa, bir üretim faktörü olarak kabul edilmiş, bu vasfı ile mülkiyetinde bulunduğu kişi ve kurumlara gelir sağlayan bir mekanizma olarak tanımlanmıştır. Cansen'e göre (2002) rant; tıpkı hırsızlık, kumar, piyango, rüşvet gelirleri gibi, milli geliri arttırmadan, kişisel gelir veya servet artışı yaratan kazanç türlerinden biri, bir transfer geliridir. Yazar (2002) rantın, kâr, kira, faiz ve ücret olarak tasnif edilen meşru faktör geliri türlerinden biri kılığında elde edildiği için fark edilemediğinden söz etmektedir. Rant terimi, gündelik yaşamda ve halk arasında rant daha çok, gayrimenkul gelirlerindeki ölçüsüz artışlar için kullanılmaktadır (Karayalçın, 20I0).

\section{Rant ve İmar Hakları İlişkisine Bakış}

Rantı, imar hakları ve imar hakları bağlamında ortaya çıkan kentsel altyapıya bağlı olarak ele alan önemli bir teorik tartışma alanı mevcuttur. Örneğin, Keleş ve Mengi'ye göre (20l4), “(b)ir toprak parçasının, önce tarımsal kullanıştan kentsel kullanışa dönüştürülmesi, sonra altyapısının hazırlanması, daha sonra da yol, otopark, yeşil alan ve meydan gibi kamu hizmetleriyle öteki kamusal yapılara kavuşması", arsa haline gelen ve altyapıya ve üstyapıya kavuşan bu toprakta bir değer artışı yaratmaktadır.' Keleş ve Mengi (20I4), söz konusu yapılardan çoğunun yapımını ya kamu tarafından gerçekleştirildiğinden ya da bunların yapılmasına, kamu yönetimlerince, planlar ve izlenceler çerçevesinde, izin verildiğinden söz etmektedir. Bu durumda, kent toprağının ederinin yükselmesinde, kamunun doğrudan doğruya bir rolü olmaktadır.
Tekeli'ye göre ise (199l) kent topraklarında oluşan değer artışları bir yandan kamunun sağladığı altyapı ve verdiği imar kararları diğer taraftan toplumsal dönüşümün ortaya çıkardığı kentsel büyüme sonucunda ortaya çıkmakta, bu değer artışının oluşmasında arsa sahibinin hiçbir üretici katkısı bulunmamaktadır. Toprağın, bireylerin iyeliğinde olduğu toplumlarda, bu artan değerin de bireylerin tekelinde kalmakta (Keleş ve Mengi, 20l4), arsa sahibi olma kişiye, toplumun oluşturduğu bir değere haksız olarak el koyma olanağı vermektedir (Tekeli, 199I, I73).

Kısaca özetlemek gerekirse, kentte bulunan bir alana imar hakkı tanındığında ve ihtiyaç duyduğu altyapı sağlandığında, rant beklentisi oluşmaktadır. Arsa, sıradan bir toprak parçası olarak algılanmamalıdır, o kentin içindedir, bir altyapı ağı vardır ve yerel yönetimce işlevi belirlenmiştir, üzerinde oluşturulacak herhangi bir yapılaşma, yine yerel yönetimlerin kontrolü ve onayı ile oluşturulabilir (Keleş vd., 1999). Kentte oluşan, kontrolsüz nüfus artışı, kentin çeperini itmekte, bu büyüme arsa gerekliliği yaratmakta, talep oluşmaktadır. Tarım toprakları bu talep sürecinin sonunda imara açılarak, kentsel arsa vasfı kazanmaktadır (Çelik, 2007; Yurtsever, 20I0). Bu durum kentsel rant oluşumunu sağlamakta, uygulamalar esnasında imar planlarının değiştirilmesi ve/veya olması gerekenden farklı uygulanması bu planların kentsel rantla olan ilişkisinden kaynaklanmaktadır (Karasu, 20l0).

Çok sayıda kuruluşa tanınmış parçalanmış imar yetkileri, imar rantlarının oluşumunu kolaylaştırmakta ve rant; imar planlarıyla yaratılan değer ve plan değişiklikleri ile yaratılan değer olmak üzere iki yaygın biçimde karşımıza çıkmaktadır. Belediyeler imar planları çerçevesinde oluşan değer artışından 18. madde uyarınca Düzenleme Ortaklık Payı alabilmektedir. Ancak çok yüksek rant yaratabilen plan değişiklikleri bu kapsamın dışındadır ve kamu buradan tekrar pay alamamaktadır (Karayalçın, 20I0). Karayalçın'a göre (20l0) uygulamada nokta işlemler için hazırlanan plan değişiklikleri rant yatakları halini almıştır ve 2004-2008 yılları arasında İstanbul'da tüm dönemlerin birkaç katı kadar imar planı değişikliği yapılması rant yaratma çabasının bir göstergesi olarak okunabilir. Özellikle, deprem sonrası konut ihtiyacının artmasıyla büyük bir arz patlaması yaşanan İstanbul'da inşa edilen binlerce yeni konut bu ihtiyaca cevap vermenin ötesinde ciddi kâr getiren yatırım araçlarına dönüşmüş ve parasını konuta yatıranların çoğu yaklaşık 2 yıllık zamanda ikinci bir ev alabilecek kadar para kazanmıştır (Ataselim, 2007). 2005 'ten bugüne kadar geçen sürede mevduata yatırım yapanlar yüzde 45.6, altına yatırım yapanlar yüzde 5I oranında getiri elde etmişken, borsanın aynı süreçteki getirisi de yüzde 30 civarında seyretmiştir. Parasını bankada veya yastık altında saklamak yerine konuta yatırmayı seçenler- konut yatırımcıları- aynı süre içinde yüzde I7I'e varan oranlarda kâr elde etmişlerdir (Ataselim, 2007). 
Bu noktada diğer tüm yatırımlar içerisinde konut sektörü üzerinde özel bir tartışma alanı açılmıştır. Nitekim Harvey (1982) ve Kratke'nin (20I4) tartıştığı, Jaeger'in de (2003) vurguladığı üzere spekülasyona dayalı gayrimenkul yatırımları artmış, konut sektörü, sermaye piyasalarında yeni mali türevler yaratan, doğrudan öteki yatırım araçları ile yarışan yatırımcılarına uzun vadede yüksek kazanç sağlayan bir yatırım aracı konumuna gelmiştir (Karayalçın, 20I0). Öte yandan, spekülasyona dayalı gayrimenkul yatırımları, örneğin, üretken yatırım için azalan olasılıkların bir ifadesi olabilir (Kratke, 1992, aktaran Jaeger, 2003). Nitekim vergilendirme, özendirme ve benzeri politikalar çevrimler arasındaki ilişkiyi sürekli olarak yeniden tanımlamaktadır ve Türkiye örneğinde olduğu gibi, 1980 öncesinde sanayiye öncelik veren devlet stratejileri, rant sektörlerini ve özel olarak da kent mekanını çarpıcı biçimde daha karlı hale getirmiştir (Şengül, 200I).

Konutta değer artışı, üzerine inşa edileceği arsayla birlikte planlama projelendirme aşamasından hemen sonra başlamakta; planlama süresi boyunca gittikçe artmakta, yapım bittikten sonra doruğa ulaşmakta; hatta o aşamadan sonra da yapılan konutun yerine, niteliklerine ve kuşkusuz talebe göre sürmektedir. Türkiye'de, 2000'li yılların ortalarına doğru, konut sektöründe ortaya çıkan büyük patlama, özellikle İstanbul'da izlenebilmektedir. Konut sahipliği, toplum için kesin bir gelecek güvencesi olarak görülmekte, birincil yatırım araçlarından biri olarak değerlendirilmektedir (Karayalçın, 20I0).

Konutun yatırım açısından bu denli büyük bir ilgi odağı olması, inşaat sektörünün ve kamusal arazilerin önemini arttırmaktadır. Kamunun sahip olduğu arazilerin üzerine yüksek yoğunlukta yeni binalar inşa edilmesi ile yaratılacak "arsa değer artışları”nı değerlendiren Cansen (2002), söz konusu değer artışının kentin ekolojisini ve ulaşım ekonomisini bozması durumunda olumsuz, yapılan inşaatların kentin veya ülkenin ekonomisine verimlilik katması, âtıl kaynakları harekete geçirmesi ve estetiğini artırması durumunda olumlu olarak algılanması gereğinin altını çizmektedir. Dolayısıyla burada rant unsurunu tartışmalı hale getiren, yatırımın değer artışı yaratması değil, değer artışının milli gelir, milli servet gibi unsurlar üzerindeki etkisidir. Bu etkinin olumsuz olması halinde projelerin Belediye'ye veya Hazine'ye sağlayacağı ek gelir ne kadar büyük olursa olsun, net bakiye eksidir (Cansen, 20I2).

Böylesi bir haksız gelir transferinin Tekeli (199I) açısından üç belirgin sonucu vardır. Bunlar; kentsel arsa rejimini spekülasyona açık hale getirerek imar düzenini çarpıtması, sanayi kesiminin çıkarları ile çelişerek emeğin yeniden üretimini pahalı hale getirmesi ve hiçbir riskle karşılaşmadan büyük getiriler sağlaması nedeniyle kapitalin üretime kaymasını zorlaştırması, bir başka deyişle kapital birikim sürecinin çarpıtılmasıdır. Karayalçın'a göre (2010) yüksek rant bölgelerinde arsa arsa olmaktan çıkmakta, imar hakları alınıp satılmaktadır. Yüksek kent rantları, yalnızca haksız kazançlara yol açmamakta, bir yandan da kentlerde yaşamsal doku bozukluklarına neden olmaktadır.

1990'ların başlarında getirilmiş olan her üç eleştirinin de bugün 2000'lerin ilk çeyreğine yaklaşırken hala geçerli olduğu görülmekte, rantla baş etmek ve yaratılan rantı kamuya kazandırmak üzere geliştirilen; kamu elindeki arsa stoklarını artırmak, mülkiyeti devretmek yerine uzun süreli kiralama yoluna gitmek, önemli düzeylere varan vergilendirmeler, kent toprağını kamulaştırmak gibi mekanizmalara dikkat çekilmektedir (Tekeli, I99I; Karayalçın, 20I0; Keleş ve Mengi, 20I4).

\section{Materyal ve Yöntem}

Çalışma; kavramsal çerçeve ve alan araştırması olarak iki düzlemde yürütülmüştür. Kavramsal çerçeve, rant olgusuna ilişkin teorik tartışmaların yanı sıra İstanbul'un kentleşme sürecinin rant bağlamında ele alınması üzerine temellendirilmiş, konuyla ilgili ana kaynaklar olarak makaleler, kitaplar, plan raporları, mevzuat ve elektronik belgeler taranmıştır. Sözü edilen kaynaklar, rant olgusuna, rantın gelişimine, rantın göstergelerine, sebep ve sonuçlarına dair önemli doneler sağlamıştır. Bu doneler takip eden bölümde alan çalışmasını kurgulamak için parametreler olarak kullanılmıştır.

Söz konusu çerçevenin, Zekeriyaköy'de rant olgusunun varlığının tespiti için sağladığı göstergeler arasında; nüfus artışı, yerleşme lekesinin büyümesi, altyapının gelişmesi, sokak sayısının artışı, konut tipleri ve niteliklerindeki değişim, arsa/konut metrekare değerlerinin artışı ve ulaşım altyapısının gelişmesi yer almaktadır. Çalışmada bu unsurlar neden-sonuç ilişkisi içerisinde ve dönemler üzerinden aktarılmış, bu süreç okuması yardımıyla rant olgusunun varlığına, hangi aktörler tarafından ortaya çıkarıldığına ve dönem içerisindeki değişimlere bakılabilmiştir.

Alandaki nüfus değişimi TÜiK nüfus verileri yardımıyla görselleştirilmiş, yerleşme lekesi Google Earth'ten edinilen 1986, 1990, 2000, 2010, 2018 tarihli haritaların karşılaştırılması ile gözlenebilmiştir. Bu tarihlerin belirlenmesinde çalışmanın ön bulguları etkili olmuştur. Alanın köy yerleşmesi olduğu dönem (1986), plan sonrası ilk özel sektör yatırımını izleyen dönem (1990), Marmara depremi sonrası (2000), 3. Havalimanının (İstanbul Havalimanı) kamuya duyurulduğu tarih (2010) ve güncel durum (2018) hava fotoğrafları aracılığıla tespit edilebilmiştir. Ulaşım altyapısına dair bilgiler gerek yerel gerek merkezi projelerle ilişkili olduğundan, konuyla ilgili kaynaklardan edinilmiş ve haritalanarak görselleştirilmiştir. Yıllara göre sokak sayısı ve sokaklar üzerindeki parsellerin gayrimenkul değerleri (arsa/konut metrekare değerleri) Sarıyer Belediyesi resmi internet sitesinden edinilerek derlenmiş ve değişim tablolaştırılmıştır. Yerleşme dokusu, konut tipleri ve niteliklerindeki değişim gerek plan raporu, hâlihazır harita gibi kaynaklar gerekse alanda yapılan gözlem, fotoğraflama, uçangöz (drone) 


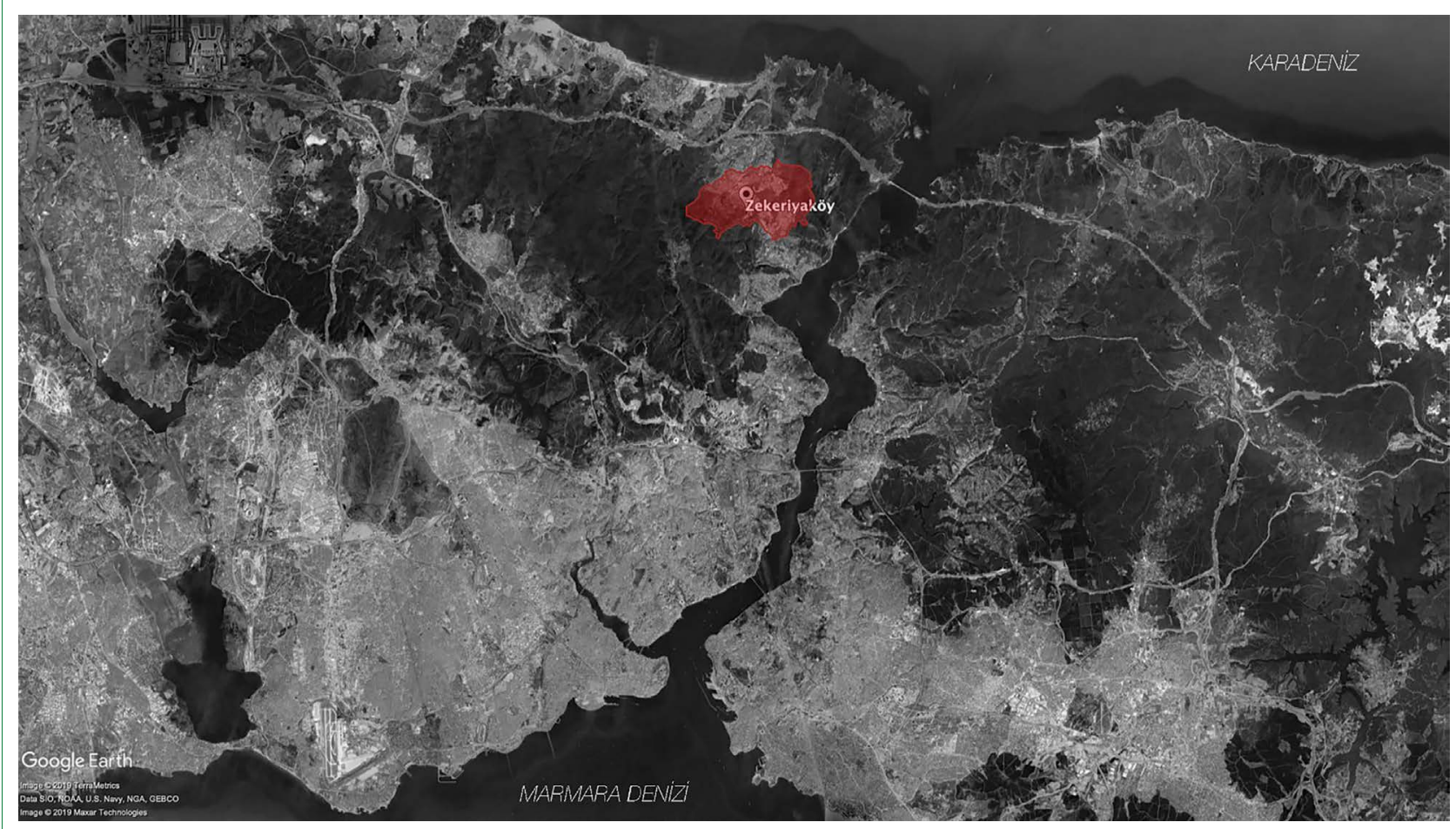

Şekil I. Zekeriyaköy, İstanbul içi konumu (URL - I).

çekimleri gibi yöntem ve araçlar yardımıyla ortaya konulmuş, mekânsal analiz yöntemiyle tespit edilerek haritalanmıştır. Uzun yıllardır Zekeriyaköy'de ikamet eden yazarın kişisel gözlemleri de çalışmayı zenginleştiren kaynaklar arasındadır.

Sözü edilen doneler başta yerel ve merkezi yönetim plan, proje ve yatırımlarıyla, ikincil olaraksa özel sektör yatırımlarıyla ilişkili görünmektedir. Bu bağlamda ilk olarak, sözü edilen plan kararları; plan tarihleri, planı yapan kurum, alanın gelişimini yönlendirecek makro kararlar ve plan değişiklikleri bağlamında ortaya konulmuş ve incelenmiş, özel sektör yatırımları ise tarihlere göre haritalanmıştır. Çalışmanın bulgular kısmında; gerek planlar gerekse kamu yatırımları ile özel sektör yatırımları dönemler bazında karşılaştırmalı olarak verilmiştir. İkinci olaraksa, sözü edilen aktörlere ve karar yapısına dair derinlemesine bilgi almak amacıyla görüşmeler gerçekleştirilmiştir. Kamu sektörünün eğilimleri İlgili Belediye yetkilisi ile yapılan görüşmenin bulgularından hareketle sunularak tartışılmıştır. Özel sektörün eğilimlerini ortaya çıkarabilmek amacıyla başvurulan görüşmeler arasında; bölgede proje üretmiş iki mimar ve Zekeriyaköy'de 5 toplu konut projesi gerçekleştirmiş olan büyük bir inşaat firması yetkilisi ile yapılan mülakatlar yer almaktadır. Bölgenin gayrimenkul pazarının gelişimini değerlendirebilmek üzere emlak danışmanları ile gerçekleştirilen görüşmelerden faydalanılmıştır.

Rant olgusunun sebep-sonuç ilişkisi içerisinde ve aktör yapısıyla birlikte tartışıldığı bu çalışmada teorik çerçevede vur- gulanmış olan toplumsal değişim ve talep olgusu bir diğer önemli aktör olan kullanıcıyı, bir diğer deyişle alan sakinlerini gündeme getirmiştir. Zekeriyaköy'de yerleşik olan kişilerin görüşlerini değerlendirebilmek üzere 318 hane halkı anketi yapılmıştır. Örneklem sayısı, Zekeriyaköy'ün 2012 yılı nüfusu temel alınarak güven seviyesi \%95, hata payı \%5,4 olarak kabul edilerek tespit edilmiştir. Anketlerin \% I'i (57 anket) köy merkezinde, \%82'si (26I anket) ise 1990 sonrasında yapılaşan alanda gerçekleştirilmiştir.

\section{Alan Çalışması Bulguları ve Tartışma}

Zekeriyaköy, İstanbul'da Avrupa Yakası'nın kuzeyinde yer alan Sarıyer İlçesine bağı 27 köyden biridir (Şekil I). 19. yüzyılın son çeyreğinde gerçekleşmiş olan 93' Harbi sırasında alana göç eden Kırım ve Kafkas kökenli aileler ile bölgede yaşam başlamıştır (İstanbul Büyükşehir Belediyesi, 2003). 1987 senesinde kadar tabiatı yeşil, yalnızca bu ailelerin ikamet ettiği, yaklaşık 70 kadar evden ibaret bir köyken (Görüşme 2) (Şekil 2), kentin büyüme sürecinde bu alan için de planlama çalışmalarına başlanmıştır. Bu planlar bağlamında alanın büyüteç altına alınmasıyla, kentin en önemli ulaşım akslarından biri sayılabilecek Maslak ile Zincirlikuyu'yu birbirine bağlayan Büyükdere Caddesi'ne olan mesafesi ve mevcut tabiatı ile büyük bir inşaat firmasının ilgisini çekmiş, burada köy dokusundan sonraki yapılaşma da bu şekilde başlamıştır. Bu firmanın inşa ettiği 3 katlı, bahçeli, müstakil konut projelerinin "varlıklı" hedef kitlesi, burada ikamet eden köy halkı- 


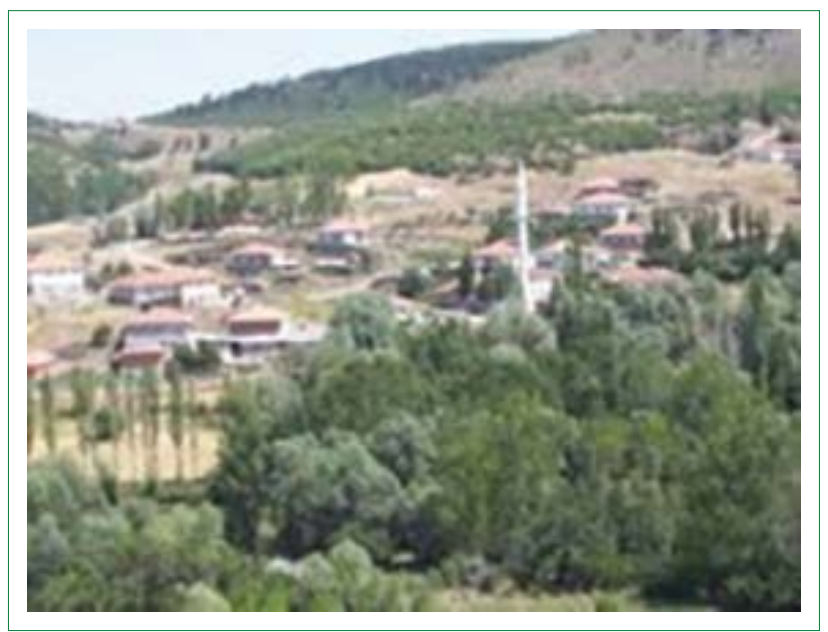

Şekil 2. Zekeriyaköy, köy yerleşimi (URL - 2).

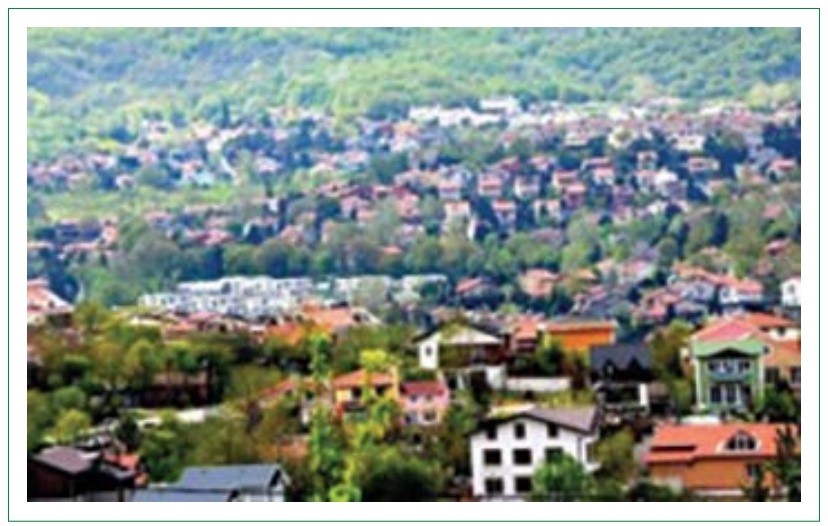

Şekil 3. Zekeriyaköy, güncel yerleşim (URL - 3).

nın sosyo-ekonomik profiliyle uyuşmamaktadır. 1990 senesinden sonraki yıllarda ise, bölge için yeni olan bu varlıklı kitle buraya daha çok çekilmek istenmiş, buna bağlı olarak hemen hemen aynı gösterişe sahip yapılar inşa edilmeye devam etmiştir. Ormanlık alanlarla çevrili bir vadiye benzeyen Zekeriyaköy, genel anlamda şehrin kaotik yapısından kaçmak isteyen aileler için bir olanak yaratmıştır (Şekil 3).

Alana üst gelir grubuna hitap eden müstakil yapılar ve lüks konutlardan oluşan güvenlikli site tipi hakimdir. Bununla birlikte, konut konseptinin ağırlıklı olarak az katlı, müstakil, bahçeli villalardan oluşması ve konutların ayrık nizamda sıralanmasıyla oluşan sokak dokusu, kent merkezinde artık güçlükle hissedilebilen mahalle yapısını yaşatma çabalarının morfolojik göstergeleri olarak yorumlanabilir. Nitekim Alan 1990 öncesinde; kahvesiyle, camisiyle, meydanıla ve sokaklarıyla bir mahalle duygusu vermektedir. Bugün bu hissi hala hem orada yaşayan halka hem de ziyaretçisine yaşatabildiği yanlış bir ifade olmayacaktır. Alan içinde altyapı ve donatıların yıllar içerisinde geliştiği görülmüştür. Daha çok üst gelir grubuna hitap eden alışveriş alanlarına, eğitim kampüslerine, spor faaliyet alanlarına, turizm ve rekreasyon alanlarına rastlanmaktadır.

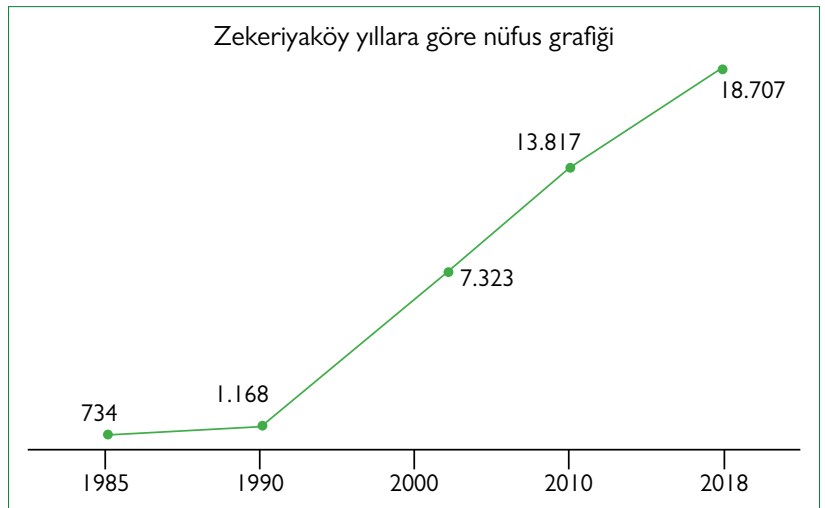

Şekil 4. Zekeriyaköy yıllara göre nüfus grafiği (URL - 4 kaynağından derlenmiş ve grafike edilmiştir).

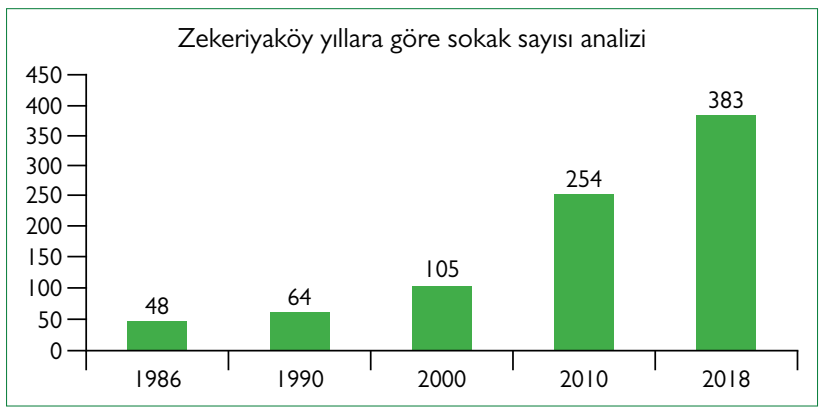

Şekil 5. Zekeriyaköy yıllara göre sokak sayısı analizi (URL - 5 kaynağından derlenmiş ve grafike edilmiştir).

Sözü edilen gelişme Zekeriyaköy’ün nüfusundan da okunabilmektedir. Nitekim alanın nüfusu 1985 yılında 734 kişi olarak raporlanmışken, 1990 senesinde I.168, 2000'de 7.323, 2010 'da 13.817 ve 2018'de 18.707 olarak kaydedilmiştir (URL - 4) (Şekil 4). Nüfustaki dramatik artışın tespiti üzerine, alanın mekânsal durumundaki gelişimine sokak sayıları üzerinden bakıldığında; 1986 yılında 48 olan sokak sayısının 2018 'e dek yaklaşık 8 kat artarak 383'e ulaştığı görülmektedir (Şekil 5).

Alanı iktisadi açıdan, rantın temel göstergesi sayılabilecek rayiç bedel bağlamında incelersek, 1986 yılında imara açılmış ve 2018 'de varlığını sürdüren sokakların rayiç bedellerinde, I,24'ten I04I,3 I'e yaklaşık 4.000 kat artış olduğu görülebilir (Şekil 6). Bu artış, 1990 yılında imara açılan sokaklar için, 0,23'ten 9/8,79'a yine yaklaşık 4000 kat olarak gerçekleşirken, 2000 yılında imara açılan sokaklar için 2 I,2 I'den 1099.03'e 250 kat, 2010 yılında imara açılan sokaklar içinse 342,92'den I 166,95'e yaklaşık 3 kat olarak gerçekleşmiştir.

Sokak sayılarındaki artış, yerleşme lekesinin de giderek büyüdüğüne ilişkin önemli bir göstergedir. Zekeriyaköy’ün 1986, 1990, 2000,2010 ve 2018 yıllarına ait hava fotoğrafları alanın zaman içindeki mekânsal gelişimini göstermektedir (Şekil 7). Bu bağlamda 1986 yılında 7,5 hektar büyüklüğünde olan alanın, 1990 


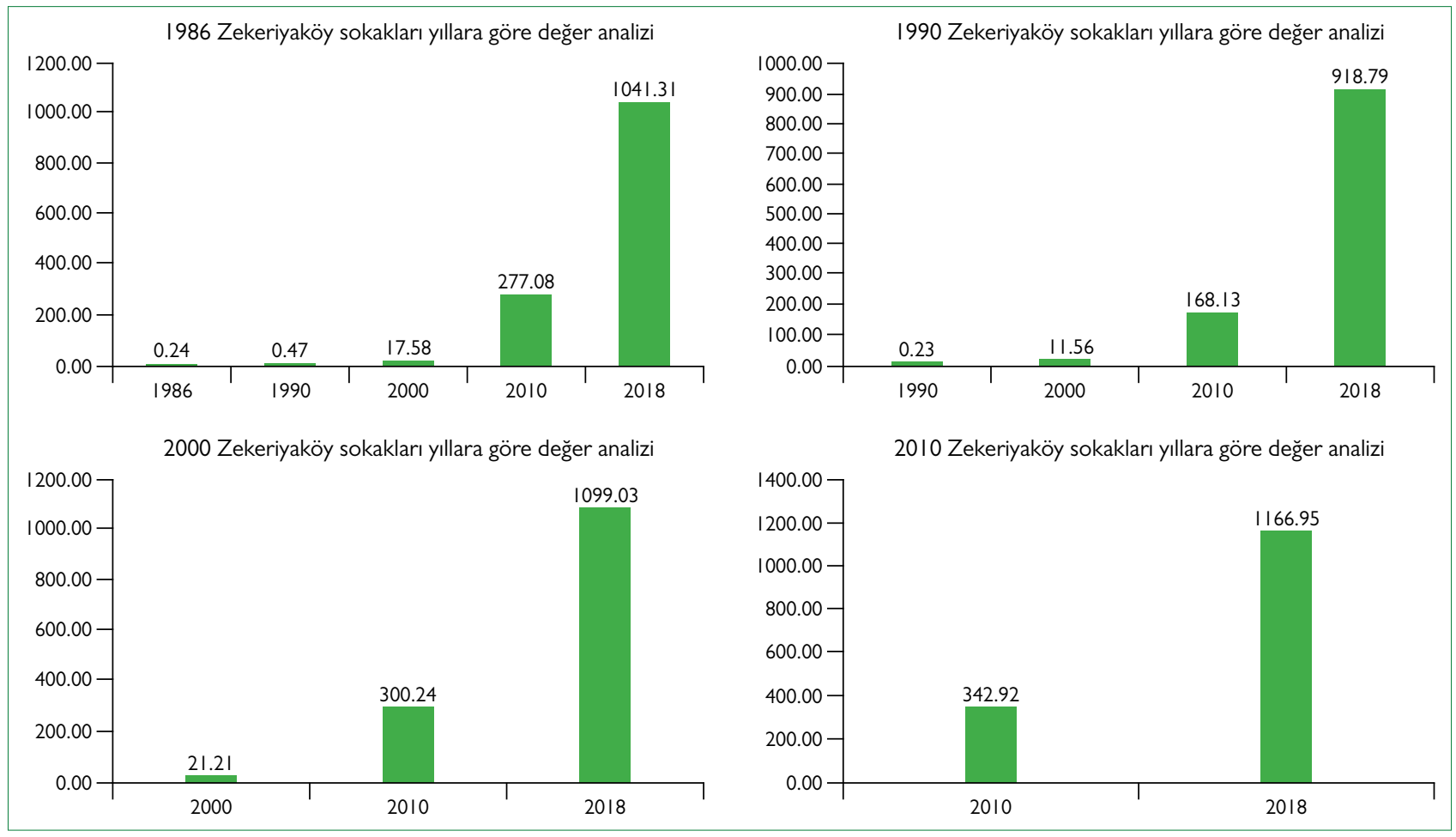

Şekil 6. Zekeriyaköy'de yıllara göre rayiç değer (URL - 5 kaynağından yazarlar tarafından derlenmiş ve tablolaştırılmıştır).

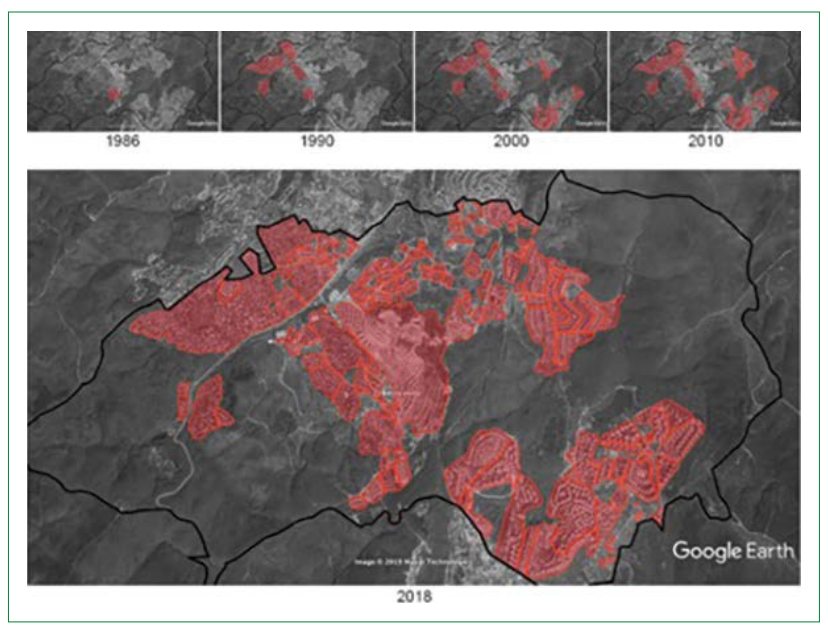

Şekil 7. Yerleşimin zaman içerisindeki alansal gelişimi (URL - 3 kaynağından, yazarlar tarafindan oluşturulmuştur).

yılında kuzey ve batıya, 2000 yılında itibarense alanın doğu ve güney kısımlarına sıçrayarak büyüme gösterdiği ve 2018 yılındaki büyüklüğünün yaklaşık 355 hektara ulaştığı görülmektedir.

Alanın kentle bağlantısının otobüs, minibüs, metrobüs, metro aksları ve durakları, karayolu aksları ve bağlantıları ile güçlendirildiği görülmektedir (Şekil 8). 2010 sonrası projeler olan Kuzey Marmara Otoyolu, 3. Boğaz köprüsü (Yavuz Sultan Selim Köprüsü) ve 3. Havalimanına (İstanbul Havalimanı) da görselde yer verilmiştir.

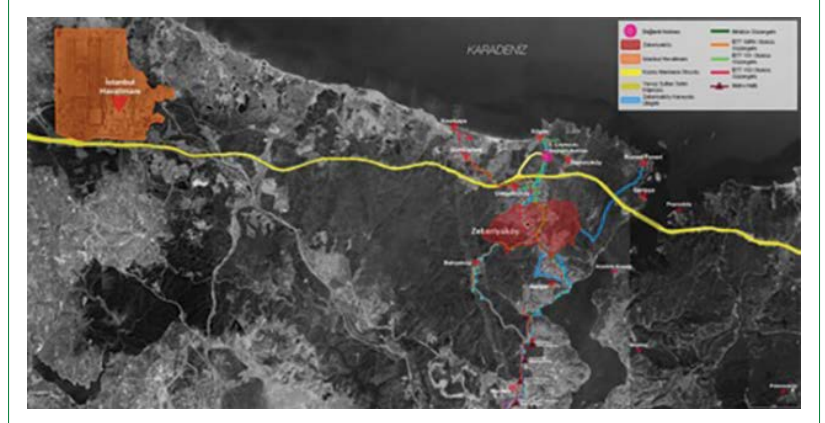

Şekil 8. Zekeriyaköy ulaşım haritası (URL - 3 kaynağından, yazarlar tarafından oluşturulmuştur).

Zekeriyaköy'e; nüfus, altyapı, sokak sayısı, rayiç bedel, yerleşim lekesi, konut tipi ve niteliklerinde değişim ve ulaşım ilişkileri açısından bakıldığında, rant göstergeleri olarak değerlendirilen bu doneler açısından dikkate değer bir artış/büyüme olduğu saptanmıştır. Aşağıda alandaki rant gelişimine dönemler ışı̆̆ında kısaca yer verilmekte, rantı ortaya çıkaran aktör ve araçlar tartışılmaktadır.

\section{0-1999 Dönemi}

1990 senesi bölge için önemli bir kırılma noktasıdır. Hemen öncesinde, 1987 senesinde bazı parsellerin imara açılmasıyla Koza İnşaat bölgeye gelmiş ve bu arsaları satın almaya başlamıştır. Alanın projelendirmesi 1989 yılına kadar sürmüş, ruhsat alımları başlamıştır. Zekeriyaköy ve komşusu Uskumruköy 


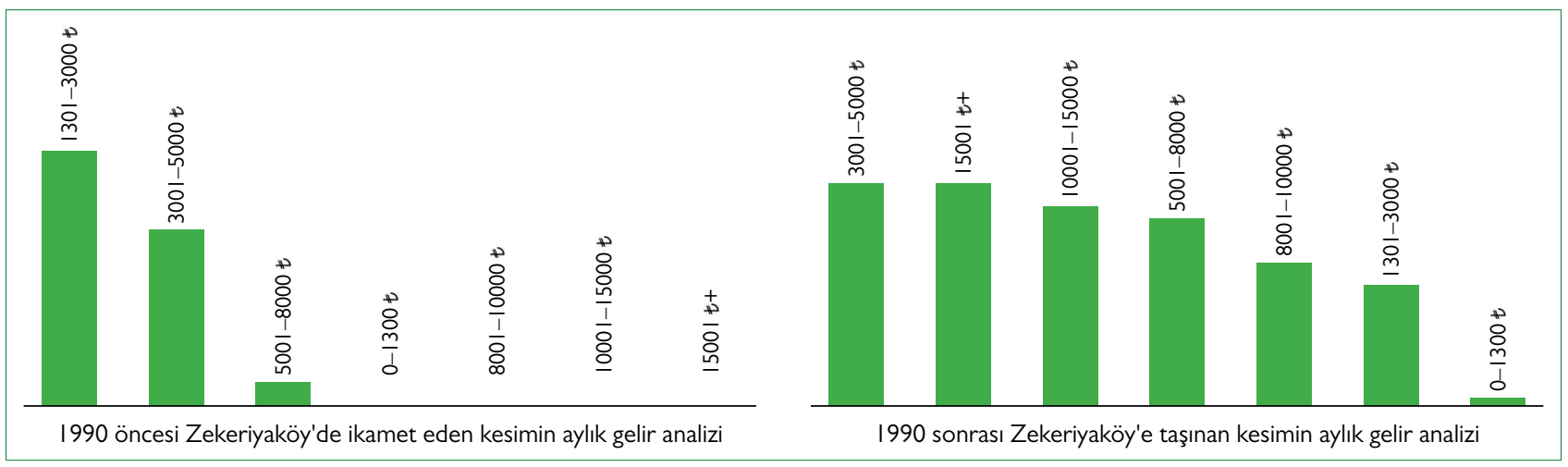

Şekil 9. Yerleşme sakinlerinin aylık gelir durumları (yazarlar tarafından oluşturulmuştur).

için hazırlanıp, Eylül 1988'de onaylanan uygulama imar planı ile Ocak 1989'da onaylanan nazım imar planı, Mart ve Nisan 1989 tarihlerindeki itirazlar neticesinde askıya alınmış, planlar yeniden hazırlanıp I99|'de IBB tarafından onaylanmıştır (Görüşme 3). Öncesinde göçler sonucu nüfus alarak oluşmuş bu köy için, 1990 senesinde değişim adına ỉBB'nin kararıyla, ilk adımın atıldığııı söylemek yanlış olmayacaktır.

Bu karar neticesinde, $1980^{\prime}$ li yılların ortasına kadar varlığını sürdürmüş köy halkı, 1990 yılından itibaren üst gelir grubundaki yeni komşularıyla tanışmaya başlamıştır. Zekeriyaköy'ün merkezi etrafında büyük bir inşaat firmasının Garanti Koza evleri adıyla inşa ettiği 1000-1500 konutluk lüks müstakil villa projesi ve çarşı alanı ile sonrasında alanın çeperine doğru projelendirilen lüks apartman daireleri Alan bir dönüm noktası olmuştur (Görüşme 2). Şekil 9'da, anket sonuçlarına dayalı olarak, Alanın yeni sakinlerinin ekonomik yapısı, köy halkının ekonomik yapısıyla karşılaştırmalı olarak verilmektedir. Buna göre, köy merkezinde yaşayan anket katılımcılarının çoğunluğunun aylık gelirinin I30I-3000 TL olduğu, bu gelir grubunu yine büyük bir oranla 300I-5000 TL'nin takip ettiği saptanmıştır. Zekeriyaköy'e daha sonra yerleşen kesimde ise; yaklaşık \%88'lik bir oranın minimum $300 \mathrm{I}-5000$ aralığından başlayarak $15.000 \mathrm{TL}+$ gelir düzeyine kadar çıktığı görülmektedir.

Bu dönemden önce alana ulaşım yalnızca Sarıyer üzerinden kişisel araçlar ve minibüslerle sağlanmakta iken, alanda faal olan yüklenici firmanın da talebiyle Karayolları Genel Müdürlüğü tarafından açılan orman yolu, bölgeyi doğrudan Maslak'a bağlamıştır (Görüşme 2, Görüşme 3). Bu hattın geliştirilmesinin sebebi olarak aynı zamanda, Zekeriyaköy ve çevre mahalleleri için gittikçe artan ilgi, bölgenin yatırım potansiyeli ve mevcut sirkülasyon hattının bu bağlamda yetersiz oluşu gösterilebilir. Dolayısıyla Orman Yolu'nun açılmasıyla alanın en önemli sorunlarından bir tanesine çözüm sağlanmışır. Bunun yanı sıra bölgenin cazibesini arttırmak veya özel aracı olmayan ve buraya taşınmayı düşünen aileler için bölgede yaşam alanları oluşturan konut kooperatiflerince, güzergahı itibariyle 4. Levent metro durağından başlayarak Maslak'tan orman yolu ile Zekeriyaköy'e gelen servis hatları oluşturulmuştur.

1990 sonrasında bölgeye taşınan kitlenin, alana taşınma nedenleri arasında, "Ev/Semtin Güzellikleri”" ve "Iş̧yerine yakın olmak" seçeneklerinin baskın olduğu görülmektedir. Bu yanıtlar baz alındığında, Zekeriyaköy'ün tercih edilmesinde; alanın doğayla bütünleşik yapısının kullanıcı açısından cazip olduğunu ve konumunun kent merkezine, hatta Maslak'ta yer alan holding ve plaza yapılarına yakınlığının önemli rol oynadığını söylemek mümkündür. 1990 sonrasında başlayan yapılaşma ve genişleme hareketi neticesinde, 1990 öncesinde 48 adet sokağın mevcut olduğu Zekeriyaköy'deki, sokak sayısı 64'e ulaşmışır.'

Bu dönem içerisinde Zekeriyaköy'ün gelişimini yönlendiren bir diğer kırılma noktası, Zekeriyaköy - Uskumruköy bölgesinin Doğal Sit Alanı ilan edilmesidir. ${ }^{2}$ Ancak daha sonra yapılan düzenlemeler belediyesince olası görülecek uygulamalara izin vermektedir ${ }^{3}$ (İstanbul Büyükşehir Belediyesi Şehir Planlama Müdürlüğü, 2003).

\section{0-20I0 Dönemi}

1999 Ağustosu'nda yaşanan ve başta İstanbul olmak üzere tüm ülke için bir kırılma noktası olan Marmara Depremi, Zekeriyaköy'ün gelişimine yön veren önemli dış faktörlerden biri olmuştur. Nitekim deprem, ülkeyi maddi ve manevi olarak sarsmış, yazılı ve görsel medyada yer alan büyük İstanbul depreminin henüz gerçekleşmemiş olduğu ile ilgili haberler toplum üzerinde büyük endişe yaratmıştır. Bu bağlamda, ilgili jeolojik raporlarda ve TOKi'nin raporunda şehrin kuzey noktalarının 3. Dereceden Deprem bölgesi oluşunun belirtilmesi (2013) ve örnek alanda az katlı müstakil konut dokusunun

\footnotetext{
Sokak olarak bahsedilen ağlara caddeler ve çıkmaz sokaklar da dâhil edilmiştir.

2 I5/I I/I995 tarihinde 7755 sayılı kurul kararı.

3 "07/I I// 996 gün ve 8849 sayılı kurul kararında Koruma Amaçlı Nazım İmar Planı yapılıncaya değin, geçiş dönemi yapılanma şartları içinde ilgili belediyesince de uygun görüldüğü takdirde 02/0I/I99I tasdik tarihli I/I000 ölçekli Zekeriyaköy - Uskumruköy Mevkii Uygulama İmar Planı'nın hüküm ve koşullarına göre uygulama yapılabileceğine" dair karar.
} 
hâkim olması Zekeriyaköy'ün yatııım potansiyelini arttırmıştır. Bu durum toplumsal dönüşüme dair bir gösterge olarak görülebilir.

2000 senesinden önce ikinci konut alanı olarak tercih edilen bir bölge iken depremden sonra yerleşmenin zemininin sağlam olması, altyapı ve ulaşım kolaylığı nedeniyle, üst gelir grubu tarafından birinci konut alanı olarak kullanılmaya başlanan Zekeriyaköy'de (TOKi, 2013) oluşan talebe bir de alanın konumu açısından kent merkezine yakınlığı eklenince, Zekeriyaköy'ün çehresi bu dönemde iyiden iyiye değişmeye başlamış, bölgedeki özel sektör yatııımlarının sayısı giderek artmıştır.

Bu dönemin belirleyicilerinden bir diğeri; III. No'lu Kültür ve Tabiat Varlıklarını Koruma Kurulunun "plan bütünlüğü açısından geçiş dönemi yapılanma şartları içinde 3194 sayılı kanunun 18. md. uygulamasında sakınca olmadığı"na dair kararıdır. ${ }^{4} \mathrm{Ni}$ tekim bu karara yapılan itirazlar sonucunda Koruma Amaçlı Nazım İmar Planı yapılıncaya kadar 3194 sayılı yasanın 18. md. uyarınca parselasyon işlemi yapılmasının mevzuata aykırı olduğu ve sit kararına müteakip bir yıl içinde koruma amaçlı nazım imar planının yapılması gerektiği ifade edilerek yapılan işlemlerin iptali kararlaştırılmıştır (İstanbul Büyükşehir Belediyesi Şehir Planlama Müdürlüğü, 2003).

Bölgenin sit alanı içinde olması, 2863 sayılı Kültür ve Tabiat Varlıklarını Koruma Kanunu'nun 17. maddesi uyarınca bir yıl içinde koruma amaçlı planın yapılması zorunluluğunun varlığı ve bölge için alınan tüm kararlar sonucunda Zekeriyaköy ve Uskumruköy için koruma amaçlı nazım imar planı çalışmalarına başlanmıştır. Bu çalışma içerisinde bina ölçeğinde fonksiyonel dağılım, kat adetleri, bina cinsleri, bina durumları; doğal yapı analizi arazi kullanım durumu bazında topoğrafya, iklim, bitki örtüsü; yanı sıra demografik yapı analizi ve Bayındırık ve İskan Bakanlığı'nın 10 no'lu genelgesine uygun jeolojik ve jeoteknik etüdler yapılmıştır. íSKi başta olmak üzere çeşitli kamu kurum ve kuruluşlarının görüşleri alınarak katılım ve destekleri sağlanmıştır (İstanbul Büyükşehir Belediyesi Şehir Planlama Müdürlüğü, 2003).

2003 yılında onanan I/I000 Ölçekli Sarıyer, Uskumruköy Zekeriyaköy Mevkii Koruma Amaçlı Uygulama Planına göre; ticaret ve konut alanlarında KAKS 0,80 , azami yüksekliği ise 9,50 metre olarak belirlemiştir. Planda ağaçlandırılması istenen alanlarda ise maksimum KAKS 0,12 ve azami yükseklik 6,50 metre kuralına uyulacak şekilde konut uygulamalarına izin verilmektedir. Yine bu plan notlarında alanda yapılacak her proje için kişi başı $10 \mathrm{~m} 2$ 'lik yeşil alan bırakılması istenmekte olup, planlama alanı içerisinde yer alan 2-B sahası olarak belirlenmiş alanların ilgili kurum görüşü ve yasal durumları müsaade etmeden uygulama yapılamayacağı belirtilmiştir. $\mathrm{Bu}$

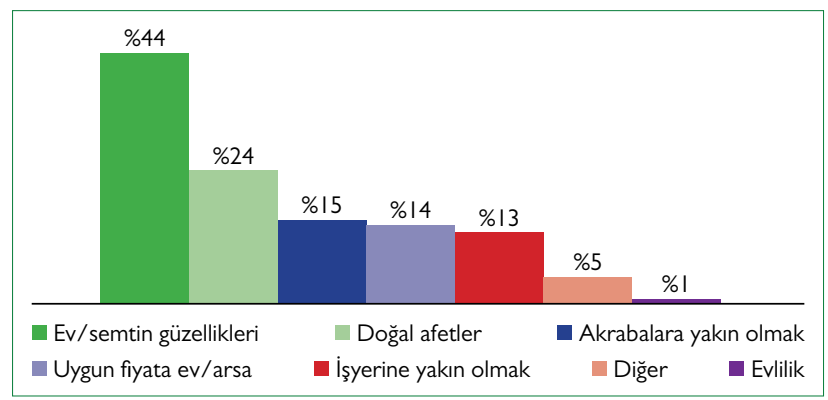

Şekil 10. Yerleşme sakinlerinin bu dönemde Zekeriyaköy'e taşınma sebepleri (yazarlar tarafından oluşturulmuştur).

tarihten başlayarak da düşük yapılaşma öngören bu plan kararlarının alanın az katlı müstakil konut gelişimini yönlendirdiği görülmektedir (Sarıyer Belediyesi, 2003).

2005 yılında IGDAŞ tarafından doğalgaz bağlantısı sağlanan alan, kentsel altyapı bakımından da gelişmeye başlamıştır. 2010 senesine gelindiğinde IBB tarafından, başta yazılı ve görsel basın aracılığıyla kamuya duyurulan Kuzey Marmara Otoyolu, 3. Boğaz Köprüsü Projesi ve 3. Havalimanı Projesinin özel sektör yatırımcıları için yarattı̆̆ı etki alan üzerinde yapılaşma hareketine yüksek oranda hız kazandırmıştır.

Bu dönemde Zekeriyaköy nüfusunda \%527 oranında artış kaydedilmiştir. Yine anket sonuçlarında da görüldüğü üzere, bu dönemde bölgeye taşınanların taşınma sebepleri arasında "Ev/Semtin Güzellikleri” ve "Doğal Afetler" seçenekleri öne çıkmaktadır (Şekil I0).

Bölgenin doğayla bütünleşik müstakil konut dokusu İstanbul halkı için hem depremden kaçmak hem de yaşama doğayı dâhil ederek kentin kaotik yapısından sıyrılmak adına itici güç olmuştur. Zekeriyaköy artık, şehir merkezine yakın ama sakin bir ortam tercih eden üst gelir grubuna mensup İstanbul halkının itibar ettiği, pahalı villalardan oluşan sitelerin yer aldığı bir bölgeye dönüşmüştür (Görüşme 2).

Sokak sayısı bu dönem 105'e ulaşmışırı. Bu verilerden de görüldüğü üzere bölgenin kılcal damarlarını oluşturan sokak ve caddeleri yayılmakta ve bölgenin yüzölçümü giderek genişlemektedir.

2010 senesinde Alanı etkileyen üç adet büyük kamu yatırım projesi duyurulmuştur. Bunlardan ilki daha sonra Yavuz Sultan Selim köprüsü ismini almış olan, 3. Boğaz Köprüsü projesidir. Proje, İstanbul'un kuzeyini Avrupa Yakası'nda Sarıyer İlçesi'ne bağlı Garipçe Mahallesi'nden, Anadolu Yakası'nda Beykoz'a bağlı Polenezköy'e bağlamaktadır. Köprü trafiğinin kent içine dağılımını sağlamak üzere az önce sözü edilen üç büyük projeden bir diğeri olan Kuzey Marmara Otoyolu Projesi, köprüyü

\footnotetext{
4 18/04/200I tarih ve I2219 sayılı kurul kararı.
} 


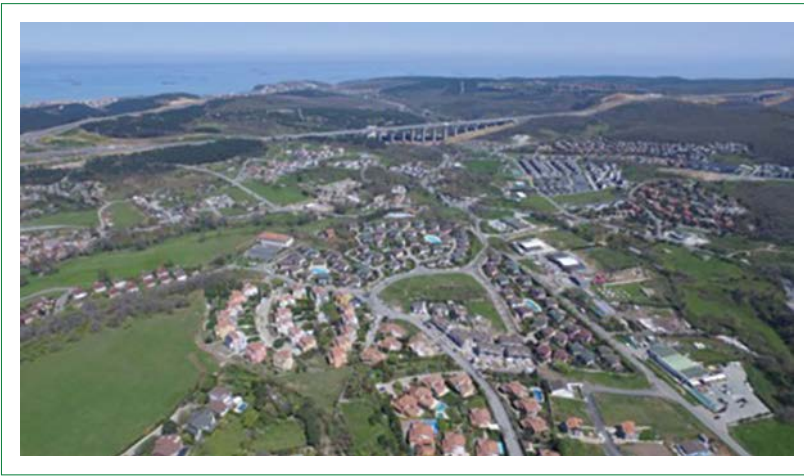

Şekil I I. Alanın deniz ve bağlantı yollarılla ilişkisi (20।7).

kuzey ormanlarından geçerek diğer ana arterlere bağlamayı hedeflemektedir. Yine bu yıl duyurulan 3. Havalimanı projesi Zekeriyaköy'ün kuzeybatısına konumlandırılmıştır. Bu üç projenin bölgede yarattıkları etki, 2010 senesinden sonra bölgedeki özel yatırımların artışıyla izlenebilmektedir.

\section{Sonrası Dönem}

Bu dönemde konut yatırımlarının önemli farklılıklarla tırmanışa geçtiği göze çarpmaktadır. 201 I senesinden sonra Alan, özel sektör yatırımı anlamında en parlak dönemine girmiştir. Bu dönemde Alana 50'nin üzerinde site inşa edilmiştir. Bu sitelerin kimisi villa konseptine uygun, kimisi ise apartman tipi konut olarak hayata geçirilmiştir. Ancak dışarıya kapalı oluşları ve özel güvenlik gibi ortak özellikleri bu yerleşmelerin tümünün "kapalı yerleşme" olarak tariflenmesini mümkün kılmaktadır. Bu konut projelerinde göze çarpan önemli özelliklerden bir diğeri ise kullanıcılarının market, ulaşım gibi ihtiyaçlarını da göz önünde bulundurmalarıdır, hatta çoğu zaman artı-değer yaratmak için havuz ve spor alanları gibi ögeler de projelere dahil edilerek lüks konut siteleri olarak tasarlanmışlardır.

20II senesinde Şişhane -Darüşşafaka metrosunun, Zekeriyaköy'e kentsel alanda en yakın noktalardan biri olan Hacıosman'a kadar uzatılması ve Hacıosman metro istasyonunun kullanıma açılması bölgeye ulaşımı daha kolay bir hale getirmiştir (Milliyet, 20I I). 2012 yılında ise Sarıyer'den Çayırbaşı'na ulaşan tünelin açılması (Küçük, 20I2) bölgeye olan ulaşım ağını genişletmiştir. Bugün alana 1990 öncesi dönemden beri Zekeriyaköy ve çevresindeki köylere Sarıyer merkezden toplu ulaşımı sağlayan minibüs hatlarının yanı sıra, kişisel araçlar, site ve kooperatiflerin düzenlediği servisler ve İstanbul Elektrik Tramvay ve Tünel İşletmeleri'nin (IETT) I5I, I 52 ve 59RK otobüs hatlarıyla doğrudan ulaşım sağlanmaktadır.

Bu dönem içerisinde bir başka önemli gelişme, Kanal İstanbul Projesi olmuştur. Kuzeyin muhafazası düşüncesini tamamen değiştiren, kentin kuzey-güney aksı üzerinde bir kanal açılarak, kanalın kenarlarında imar çalışması başlatılmasını amaçlayan ve

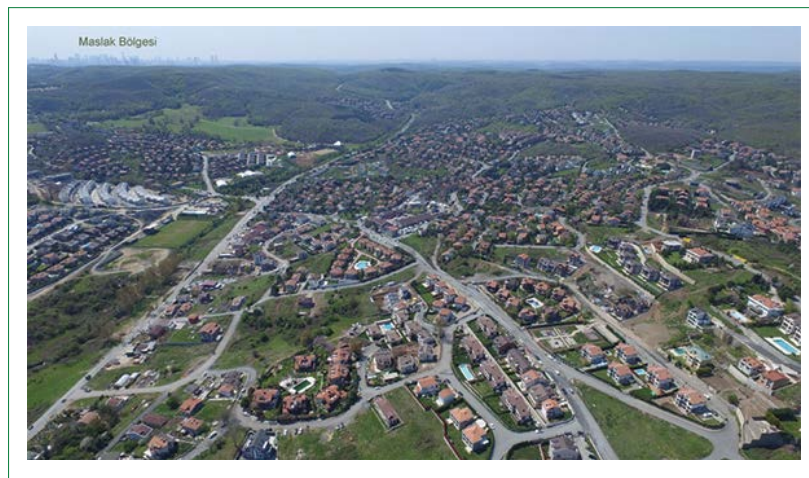

Şekil I 2. Alanın Maslak ve orman alanlarıyla ilişkisi (20।7).

dolayısıyla Zekeriyaköy'ü yakından ilgilendiren proje 20I I yılı Genel Seçimlerinden önce halka duyurulmuştur (Keleş, 20।5).

2014 senesinde, yerel yönetim kararınca köy statüsünden mahalle statüsüne geçen Zekeriyaköy'ün konut profili 2017 senesinde artık daha önce de bahsedildiği gibi, lüks villa ve apartman tipi konutlardan oluşmaktadır. Bugün Alanın karakterini yoğun biçimde, müstakil villalardan ve villa tipi konutlardan oluşan kapalı yerleşmeler tanımlamaktadır. 1990 öncesinden beri varlığını sürdüren köy dokusu villalardan oluşan siteler tarafından çevrelenmiş, bölgenin doğusunu, yani "Siteler Bölgesi” olarak adlandırılan kısmını ise lüks apartmanlar doldurmuştur. Büyük konut projelerinin yanı sıra parsel bazında küçük yapılaşmalar olduğu da görülmektedir. Bu yapılaşmalar genelde daha bireysel projeler olup, bir veya iki villanın oluşturduğu daha ufak ölçekte yapılaşmalardır. Bölgenin tamamı henüz yapılaşmamış olup, hala inşaatı devam eden projelere de rastlanmaktadır. Alanın deniz, bağlantı yolları, ormanlık alanlar ve Maslak'la ilişkisi Şekil I I ve I2'den izlenebilir.

Üst gelir grubunun bölgede başlatılan imar hareketine yanıt üretmekte daha avantajlı oluşu ve yaratılan arza karşılık verebilmesi alanın ekonomik anlamdaki değişimini de göstermektedir. Bu bölgeyi I 5 senedir portföyünde bulunduran bir emlak danışmanından alınan bilgiye göre (Görüşme 5); 2003-2004 senelerinde, 50 bin dolara bölgeden ev almak mümkün iken, bugün bu fiyatlar I milyon 400 bin, I milyon 500 bin dolara ulaşmıştır. Alan, genellikle $A$ ve $B+$ kitle grubuna hitap etmektedir. Alanda 17 senedir emlak danışmanlığı yapan bir diğer danışmanın gözlemleri doğrultusunda ise, bu bölgedeki emlak fiyatlarının her zaman, her gün yükselmeye devam ettiği, hiç düşüş olmadığı, \%।00'lük bir artışın söz konusu olduğu mülakat yapılan kişinin görüşüyle saptanmıştır (Görüşme 4).

Bölgedeki bir diğer konut projesi Emlak Konut ve TOKI iş birliğiyle hayata geçirilmiş olan KÖY Projesi'dir. 5I,3 hektarlık alan üzerinde konumlandırılmış ve inşaatı devam eden Proje, TOKi tarafından hazırlanan rapora göre (20I3) kısmen boş, kısmen ağaçlıklı bir alan üzerine yapılanmıştır. 
Dönemler Kamu plan ve yatırımları ile ilgili aktörler

\section{Kamu plan ve yatırımları}

1990 öncesi

- Zekeriyaköy'de planlama çalışmaları başladı.

- Ocak 1988'de I/ I000 ölçekli Uygulama

İmar Planı (UiP) onaylandı.

- Eylül I988'de, I/5000 ölçekli Nazım

İmar Planı (NiP) onaylandı.

• Eylül 1990'de Zekeriyaköy ve komşusu

Uskumruköy için IBB'den I/ 1000

UiP'lerin yeniden hazırlanması ile ilgili karar çıktı.

\section{Aktörler}

- Sarıyer Belediyesi.
- İstanbul Büyükşehir Belediyesi

\section{Kamu plan ve projelerine bağlı gelişen özel sektör yatırımları}

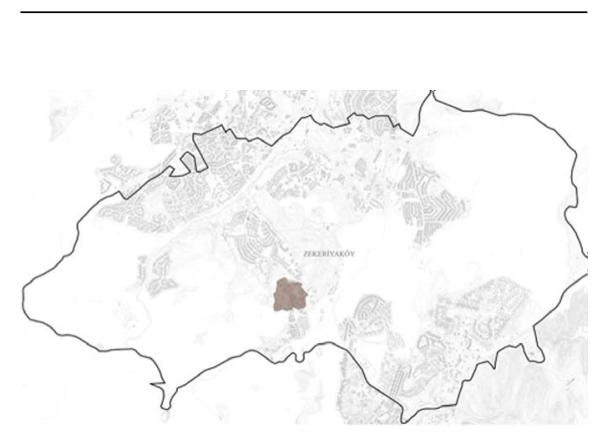

1990-1999

- 199|'de İBB, Zekeriyaköy ve komşusu Uskumruköy için I/ I 000 ölçekli

Uygulama İmar Planları değişikliklerini onayladı.

- Kasım 1995 'te 7755 Sayilı Kurul kararı ile alan Doğal Sit Alanı ilan edildi.

- Kasım 1996'da 8849 Sayilı Kurul kararında, Koruma Amaçlı NiP'te, 1991 yılı onaylı I / 1000 ölçekli UiP hüküm ve koşullarına göre uygulama yapılabileceğine karar verildi.

\begin{tabular}{|c|c|c|}
\hline 000-2010 & 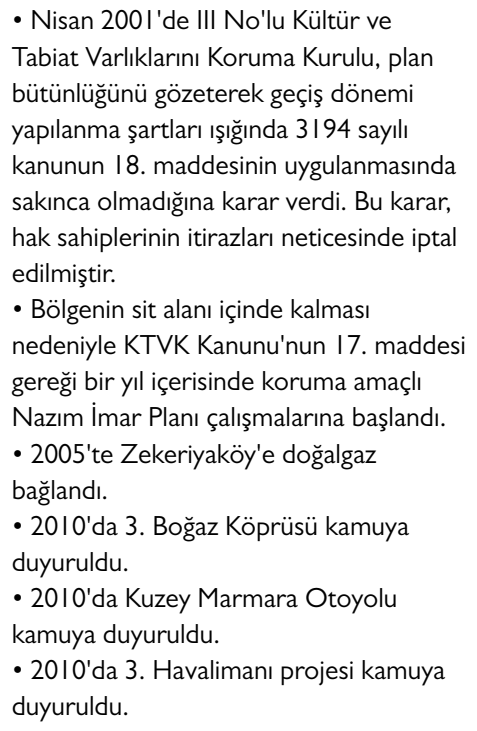 & $\begin{array}{l}\text { • IGDAŞ } \\
\text { • İstanbul Büyükşehir Belediyesi } \\
\text { • Kültür ve Tabiat Varlıklarını } \\
\text { Koruma Kurulu }\end{array}$ \\
\hline 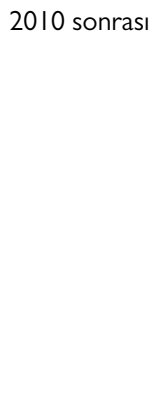 & $\begin{array}{l}\text { • } 20 \text { I I'de Darüşşafaka'ya kadar ulaşan } \\
\text { Taksim - Levent metro hattının devamı } \\
\text { olan Hacıosman İstasyonu açıldı. } \\
\text { • } 20 \text { I2'de Sarıyer - Çayırbaşı tüneli açıldı. } \\
\text { • 20।4'de Zekeriyaköy mahalle statüsü } \\
\text { kazandı. } \\
\text { • } 2016 \text { 'da Kuzey Marmara Otoyolu açıldı. } \\
\text { - 20।6'da 3. Köprü "Yavuz Sultan Selim } \\
\text { Köprüsü" adıyla açıldı. } \\
\text { • 20।8'de 3. Havalimanı "İstanbul } \\
\text { Havalimanı" adıyla açıldı. }\end{array}$ & $\begin{array}{l}\text { - Karayolları Genel Müdürlüğü } \\
\text { - Ulaştırma, Denizcilik ve } \\
\text { Haberleşme Bakanlığı } \\
\text { - TOKi } \\
\text { - Cengiz } \\
\text { - Kolin } \\
\text { - Limak } \\
\text { - MAPA } \\
\text { - Kalyon Ortak Girişin Grubu } \\
\text { - Devlet Hava Meydanları } \\
\text { Isşletmesi Genel Müdürlüğü }\end{array}$ \\
\hline
\end{tabular}

- İstanbul Büyükşehir Belediyesi - Sariyer Belediyesi.

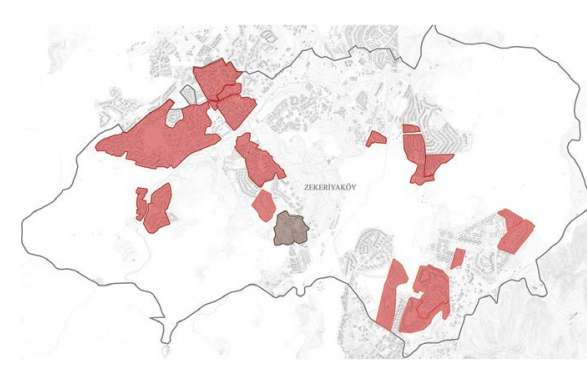

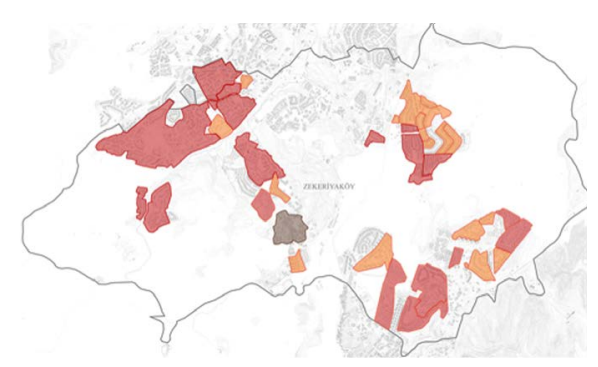

Şekil 13. Dönemlere göre kamu ve özel sektör plan, proje ve yatırımları (yazarlar tarafından oluşturulmuştur). 
Bu bağlamda Zekeriyaköy ve çevresindeki yatırım projelerini incelemek, alandaki yatırım potansiyelini görmek açısından önemli olacaktır. Sarıyer Belediyesi'ne ait, "Sarıyer Kalkınma Eylem Planı"nda yer alan bilgiler ışığında bu yatırımlardan biri olan "Bahçeköy - Zekeriyaköy - Uskumruköy Hafif Metro Sistemi" projesi bölge yakınına ulaşımı amaçlayan projeler arasında yer almaktadır (URL - 6).

Bölgenin kent içerisindeki konumu, ulaşımın kolaylaşması için planlanan yatırımlar ve alan sakinleri için tüm gündelik ihtiyaçların özel sektör yatırımları ışığında bölge içinde ya da yakın bir konumda yer alması, alanın yatırım yapmayı düşünen inşaat firmaları için tercih edilebilirliğini arttırmaktadır (Görüşme I). Zekeriyaköy'de yaşanan bu değişim bugün hala devam etmektedir. 2005 senesi verileriyle 2017 verileri karşılaştırıldığında bölgede yer alan arsaların metrekare satış fiyatının 500 Amerikan Doları'ndan, 1000 Amerikan Doları'na çıktığı gözlenmektedir (Görüşme 2). Doların kur değerindeki artış ta göz önünde bulundurulduğunda, konut fiyatlarının varmış olduğu nokta daha iyi anlaşılabilmektedir.

Bu denli büyük projelerin ve mega projeler olarak isimlendirilen kamu yatırımlarının şehrin büyümesinde etken olduğu, yepyeni yaşam ve yatırım trendleri ortaya çıkarttığı düşüncesi bölgeye yatırım yapan büyük inşaat firmalarından birinin yönetim kurulu başkanına göre, İstanbul içerisindeki değeri artmakta olan yeni bölgeler arasındaki Zekeriyaköy'ün potansiyelini en yükseğe çıkartmaktadır. Aynı zamanda yolcu kapasitesi bu denli yüksek olan bir havalimanı projesinin ve 3. Boğaz Köprüsü gibi dev ölçekli bir projenin bölgeye olan yakınlığının alanı uluslararası ölçüde değerli bir hale getireceğini düşünmektedir (Görüşme I). Aşağıda, sözü edilen kamu plan, proje ve yatırımları dönemlere göre verilmiş, bunlara bağlı olarak gelişen özel sektör yatırımları yine dönemlere göre haritalandırımıştır (Şekil I3).

Tabloda 1990 öncesi köy yerleşimi kahverengiyle gösterilmiştir. 1990-1999, 2000-2010 ve 2010 sonrası dönemler için alanda gerçekleşen özel sektör yatırımları sırasıyla kırmızı, turuncu ve pembe renkle ifade edilmiştir.

3. Köprü, 3. Havalimanı ve Büyük Konut Projeleri, anket katılımcıları tarafından nüfus artışına ve trafik yoğunluğuna sebep olacağı gerekçesiyle olumsuz olarak değerlendirilmiştir. Ancak bu projelerin mülkiyette değer artışı sağlayacağı ve bölgeye ulaşımı kolaylaştıracağı düşüncesi katılımcılar tarafından kabul edilmekte, alanın sosyal profilinin değişeceği öngörülmektedir. Bu projelerin hava kirliliği, ormanların yok edilmesi ve kentleşme baskısının toprak iş̧̧isine zarar vermesi gibi etkileri katılımcılara sorulduğunda, çoğunluk bu olumsuzlukların ortaya çıkabileceğini belirtmişse de bir kısım için, bu parametrelerin söz konusu yatırımlardan etkilenmeyeceği düşüncesi anketlere yansımışıtır.

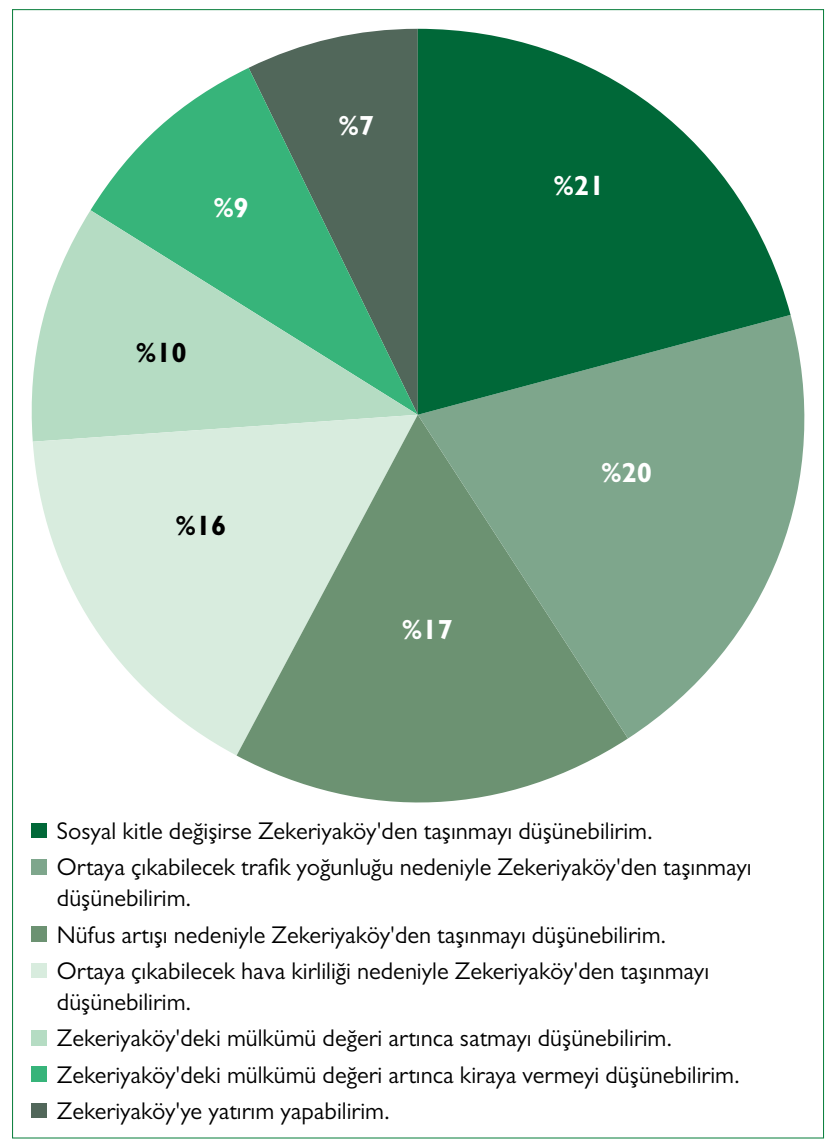

Şekil I4. Mülkle ilgili değişikliğin olası nedenleri (yazarlar tarafından oluşturulmuştur).

Yukarıda sözü edilen bu değişimler sonucunda alan sakinlerinin mülklerinde ve/veya yaşam biçimlerinde değişikliğe gitme eğilimlerine bakıldığında; \%64'ünün mülkte değer artışı gibi olasılıklara rağmen böylesi bir değişikliği düşünmedikleri belirlenmiştir. Değişiklik düşünen \%36'lık kesim alandaki sosyal kitlenin değişmesi, ortaya çıkabilecek trafik yoğunluğu, alandaki nüfus artışı ve/veya oluşabilecek hava kirliliği gibi sebeplerle söz konusu bir değişime sıcak bakabileceklerini bildirmişlerdir (Şekil 14). Bu durum, 1990 sonrası alana yerleşen varlıklı kesim açısından, Zekeriyaköy'de rant etkisindeki mülkün değişim değerinin değil, kullanım değerinin önde olduğuna dair önemli bir gösterge olarak okunabilir.

\section{Sonuç}

Bu çalışmada, Sarıyer ilçesi sınırları içerisinde yer alan ve 19. yüzyılın son çeyreğinde oluşan 70 hanelik bir köy olan Zekeriyaköy'deki rant olgusu araştırılmış, rant yaratan faktörler ve aktörler belirlenmiştir. Alanda tespit edilen faktörler arasında; nüfus artışı, yerleşme lekesinin büyümesi, altyapının gelişmesi, sokak sayısının artışı, konut tipleri ve niteliklerindeki değişim, arsa/konut metrekare değerlerinin artışı ve ulaşım altyapısının gelişmesi yer almaktadır. 
Rantı yaratan ve hızlandıran ana faktörlere bakıldığında üç dönem öne çıkmaktadır. Alan için belirleyici ilk kırılma noktası, 1990 senesinde IBB'nin kararıyla, uygulama ve nazım imar planlarının onaylanmış olmasıdır. Bu kararla birlikte, köy yerleşmesinin dışında ilk yapılaşmanın önü açılmıştır. 1999 Marmara depremi Zekeriyaköy için belirleyici bir diğer dönemi getirmiştir. Deprem sonrası ilgili jeolojik raporlarda ve TOKI'nin raporunda şehrin kuzey noktalarının 3. dereceden deprem bölgesi oluşunun belirtilmesi ve alanda az katlı müstakil konut dokusunun hâkim olması Zekeriyaköy'ün yatırım potansiyelini arttırmıştır. 2010 senesi, bugün tamamlanmış olan, üç adet büyük kamu yatırım projesinin halka duyurulduğu tarih olması sebebiyle Zekeriyaköy'ün gelişimini doğrudan yönlendiren yeni bir dönemin habercisi olmuştur. Bu projeler; İstanbul'un kuzeyini Avrupa Yakası'nda Sarıyer İlçesi'ne bağlı Garipçe Mahallesi'nden, Anadolu Yakası'nda Beykoz'a bağlı Polenezköy’e bağlayan Yavuz Sultan Selim köprüsü, köprüyü kuzey ormanlarından geçerek diğer ana arterlere bağlayan Kuzey Marmara Otoyolu ve Zekeriyaköy'ün kuzeybatısına yer alan 3. Havalimanı'dır. Bu üç projenin bölge üzerindeki belirleyicilikleri, kamuya duyuruldukları 2010 senesinden sonra alandaki konut yatırımlarının artış hızı ile okunabilmektedir. 20II-20I5 yılları arasında bölgede, kimisi villa konseptine uygun, kimisi ise apartman tipi konut olarak hayata geçirilen ve "kapalı yerleşme" olarak tariflenebilecek, toplam 33 adet özel konut projesi tamamlanmıştır. Bu özel konut projelerinin yanında 5I,3 hektarlık alana yayılan, Emlak Konut ve TOKi iş birliğiyle gerçekleştirilen KÖY Projesi de, alanı etkileyeceği öngörülen projeler arasındadır. 20I I senesinde İstanbul metrosunun, Zekeriyaköy'e kent merkezindeki en yakın nokta olan Hacıosman durağının açılması, 2012 senesinde Sarıyer Çayırbaşı tünelinin inşasının tamamlanması gibi yatırımlar bölgeye ulaşımı kolaylaştırmıştır. Bugün alanın erişimini artırarak gelişimini etkileyecek büyük projeler arasında bir kamu yatırımı olan 32 km.'lik Gayrettepe - Kemerburgaz - 3. Havalimanı raylı sistem hattı, Sarıyer - Kilyos tüneli ve 3. Havalimanı'nın yakınında bulunan 87,3 hektarlık alanda projelendirilen uluslararası bir kongre ve fuar merkezi görülmektedir.

Zekeriyaköy'de rant olgusunu yaratan ve büyüten ana faktör ve aktörler, teorik çerçeveyle uyumlu biçimde, alana doğrudan yapılan yatırımlar ve yatırımları mümkün kılan imar planları ile, merkezi organların plan, yatırım ve projeleri olarak öne çıkmıştır. Bu bağlamda rantın ortaya çıkışında etkin olan aktörler; yerel yönetim ve merkezi yönetimin ilgili organları olarak görülmektedir. Parçalanmış imar yetkilerinin bir sonucu olarak rant olgusu ortaya çıkmış, yapılan plan ve yatırımlar özel sektör yatırımlarını tetiklemiştir. Bu süreçte ortaya çıkan rantın, kent merkezlerinde, yüksek emsale dayalı rant gelişiminden farklı oluşu, alanın, Kültür ve Tabiat Varlıklarını Koruma Kurulu tarafından doğal sit alanı ilan edilmesinin bir sonucudur. Ancak, sadece düşük emsalli yapılaşma etkisinde kalmayan, diğer kamu plan ve yatırımlarıyla da gelişen Zekeriyaköy'de planlama, imar hakları aracılığıyla rant yaratmış ve/veya rantı tetiklemiştir.

Alandaki rant unsuru açısından ayırt edici bir konu 1999 Marmara depreminin ardından İstanbul'un deprem riskli güney kesimlerinde yaşamakta olan kişilerin kuzeye, deprem güvenlikli alanlara doğru yer değiştirme eğilimleri olmuştur. Bu eğilim; alanda zaten 1990'lardan beri var olan konut geliştirme projeleri, alanın doğa ile iç içe yapısı ve kent merkezine yakınlığı gibi unsurlarla birleştiğinde, özellikle üst gelir grubu için çekici bir unsur haline gelmiştir. Dolayısıyla, hedef kitleye bağlı olarak konut tiplerinde ve özelliklerinde ortaya çıkan değişiklik de sözü edilen rantın sebepleri arasındadır.

Zekeriyaköy'deki değer artışları, kent merkezine göre konumu bağlamında değerlendirildiğinde "farklılık rantı”na örnek gösterilebilirken, Alanda 1990 öncesinden beri toprak mülkiyetine sahip kimselere veya 1990 senesinde satın alınan parsellerin yatırımcılarına artı-değer yaratması açısından "tekel rantı"na örnek olarak gösterilebilir. Gerek zaman içerisinde oluşmuş olan rantı gerekse büyük projelerin alanda yaratması beklenen rantı değerlendiren alan sakinlerinin önemli bir bölümü konut ve/veya arsasını satmayı düşünmediğini ifade etmiştir. Yaşam koşullarının kent merkezine oranla daha olumlu bulunması nedeniyle, yaşamak için tercih edilen bu alanda edinilen gayrimenkulün kullanım değerinin değişim değerine tercih edildiği görülmüştür. 


\section{KAYNAKLAR}

Aydemir, Ş., Erkonak Aydemir, S., Şen Beyazlı, D., Ökten, N., Öksüz, A. M., Sancar, C., Özyaba, M., Aydın Türk, Y. (2004). Kentsel Alanların Planlanması ve Tasarımı. Trabzon: Akademi Kitabevi.

Ataselim, M. (2007, 4 Eylül). Ne borsa ne bono şampiyon konut!. arsiv.sabah. com.

Bu Projeler İstanbul'u Rahatlatacak. (2011, 29 Kasim). Milliyet.

Cansen, E., (2002, 20 Mart). Ele giden firmalar. www.hurriyet.com

Cansen, E., (2012, 25 Şubat). İstanbul'un taşı toprağı ranttır. www.hurriyet. com

Çelik, K. (2007). Tarım Topraklarının Kentsel Arsa Olarak İmara Açılmasının Getirmiş Olduğu Sorunlar. Ankara: TMMOB Harita ve Kadastro Mühendisleri Odası 11. Türkiye Harita Kurultayı.

Evans, A. W., (1999). On minimum rents: Part 2, a modern interpretation. Urban Studies, 36, 2305.

Harvey, D., (1974). Class-Monopoly Rent, Finance Capital and The Urban Revolution. Regional Studies, 8, 239-255.

Harvey, D., (2015). Sermayenin Sınırları. Utku Balaban (Çev.). İstanbul: Yazilama.

İstanbul Büyükşehir Belediyesi Şehir Planlama Müdürlüğü, (2003). 1/5000 Ölçekli Zekeriyaköy - Uskumruköy Bölgesi Koruma Amaçlı Nazım İmar Planı.

Jaèger, J., (2003). Urban land theory: A regulationist perspective. International Journal of Urban and Regional Research, 27, 233-249.

Karayalçın, M., (2010). Konut Bunalımı, Kent Rantları ve Proje Muhafızları. Ankara: İmge Kitabevi.

Karasu, M. A., (2010). Kentsel Rant, İmar Planları ve Siyasi Yozlaşma. Toprak Mülkiyeti Sempozyumu, Dü. Sonay Bayramoğlu Özuğurlu). Ankara: Memleket Yayınları.

Keleş. R., vd. (1999). Kentsel Toprak Rantının Kamuya Kazandırılması. Ankara: Öteki Yayınevi.

Keleş, R., Mengi, A. (2014). İmar Hukukuna Giriş. Ankara: İmge.

Keleş, R., (2015). 100 Soruda Türkiye'de Kentleşme, Konut ve Gecekondu. İstanbul: Cem Yayınevi. (Dü. Bülent Eryılmaz)

Krätke, S., (2014). Cities in Contemporary Capitalism. Internatıonal Journal of Urban and Regional Research, 28, 5, 1660-77.

Küçük, M. (2012, 09 Eylül). 1 Saatlik Yol 5 Dakikaya İndi. www.hurriyet.com. $\operatorname{tr}$

Lipietz, A., (1985). A Marxist Approach to Urban Ground Rent. BALL (ed.). Land Rent, Housing and the Planning System, Croom Helm, London.

Sarıer Belediyesi. (2003). 1/1.000 Ölçekli Sarıyer, Uskumruköy - Zekeriyaköy Mevkii Koruma Amaçlı İmar Planı Plan Notları. İstanbul: Sarıyer Belediyesi.

Scott, A. J., (1976). Land and Land Rent: An Interpretative Review of the French Literature. Progress in Geography, 9, 102-45.

Şengül, T., (2001). Kentsel Çelişki ve Siyaset. İstanbul: Demokrasi Kitaplığı. Tekeli, İ., (1991). Kent Planlaması Konuşmaları. Ankara: TMMOB Yayınları. Toplu Konut İdaresi Başkanlığı. (2013). İstanbul İli, Sarıyer İlçesi, Zekeriyaköy Toplu Konut Alanı - 1/5.000 Ölçekli Koruma Amaçlı Nazım İmar Planı ve 1/1.000 Ölçekli Koruma Amaçlı Uygulama İmar Planı Açıklama Raporu. İstanbul: Toplu Konut İdaresi Başkanlığı.

Turan, M., (2009). Türkiye'de Kentsel Rant. Ankara: Tan Kitabevi.

Üstünel, Prof. Dr. B., (2001). Ekonominin Temelleri. İstanbul: Dünya Yayınlar1.

Yurtsever, H., (2010). Rantın Vergilendirilmesi. (Toprak Mülkiyeti Sempozyumu, Dü. Sonay Bayramoğlu Özuğurlu). Ankara: Memleket Yayınları.

\section{INTERNET KAYNAKLARI}

URL - 1: Google Earth Hava Fotoğrafları, (Erişim tarihi: 2016 - 2019)

URL - 2: www.esosyo.com, (Erişim tarihi: 18 Temmuz 2019)

URL - 3: https://www.sariyerposta.com, (Erişim tarihi 06 Ağustos 2018)

URL - 4: http://www.nufusu.com/il/istanbul-nufusu, (Erişim tarihi: Haziran, 2017)

URL - 5: https://ebelediye.sariyer.bel.tr/DIGIKENTEBELEDIYE/faces/ page/rayic.jsp, (Erişim tarihi: Kasım, 2018)

URL - 6 http://sariyer.bel.tr/ckuploads/ckfiles/SKEP3. pdf?time $=1556286548382$, (Erişim tarihi: 21 Nisan 2020$)$

\section{GÖRÜŞMELER}

Görüşme 1 - 15 Haziran 2016.

Görüşme 2 - 22 Mayıs 2017.

Görüşme 3 - 23 Mayıs 2017.

Görüşme 4 - 22 Haziran 2017.

Görüşme 5 - 22 Haziran 2017. 